\title{
Pharmaceutical Supply Chains and Management Innovation?
}

\begin{abstract}
Purpose: This research evaluates the implementation of innovative programmes within the downstream domain of the Pharmaceutical Supply Chain (PSC) with the aim of informing improved service provision.

Design/methodology/approach: A mixed-method approach was used to assess to what extent innovation could be adopted by hospital and community pharmacies to improve the delivery process of pharmaceutical products. Unstructured interviews and 130 questionnaires were collected and analysed to identify factors that support or prevent innovation within PSC processes.

Findings: The analysis led to the generation of the Innovative Pharmaceutical Supply Chain Framework (IPSCF) that provides guidance to healthcare organisations about how SCM problems could be addressed by implementing innovative approaches. The results also indicated that the implementation of Lean and Reverse Logistics practices, supported by integrated Information Technology (IT) systems, could help healthcare organisations to enhance their delivery in terms of quality (products and service quality), visibility (knowledge and information sharing), speed (response to customers and suppliers needs) and cost (minimisation of cost and waste).

Practical implications: The study's recommendations have potential implications for supply chain theory and practice and particularly for pharmacies in terms of innovation adoption. The IPSCF provides guidance to pharmacies and healthcare organisations to develop more efficient and effective supply chain strategies.

Originality/value: This research contributes to academic literature as it adds novel theoretical insights to highly complex delivery process innovation.
\end{abstract}

\section{Introduction}

Pharmacies are a key link between healthcare services and patients, as they are responsible for dispensing and managing pharmaceuticals and offering value added services to prolong life (Edwards et al., 2018). Considering healthcare organisations' crucial role in supporting patient care, investments and constant improvement are required for the healthcare system to operate efficiently and satisfy the increased demand for high quality services (Sayed et al., 2018). However, they face the challenge of minimising the cost of healthcare services while sustaining or enhancing the level of quality they provide (Narayanamurthy et al., 2018; Papalexi et al., 2020). Data presented by Statista (Mikulic, 2019) suggests that worldwide drug expenditure will continue to grow and as of 2018 approximately $\$ 1.2$ trillion will have been spent on medicines with an expected increase to $\$ 1.52$ trillion by 2023 . Furthermore, the global medical waste is estimated to be $\$ 13.3$ billion in 2020 (Markets and Markets Research, 2018), which includes the perceived high level of wastage associated 
with pharmaceuticals and contributes to the increase of the overall healthcare cost (Cherrett et al., 2012; Papalexi, 2017). Healthcare literature suggests that the adoption of improvement approaches and innovative interventions could enhance healthcare supply chains and assists in reducing waste and providing improved services (Bhakoo et al., 2012; Pohjosenperä et al., 2018).

The investigation into aspects of innovation that can be adopted within the healthcare sector, which has been a popular but not yet fully established subject, can offer a significant contribution to knowledge (e.g. Govindan et al., 2015; Bamford et al., 2015). In addition to this, research focused particularly on the PSC has been inspiring (Kumar et al., 2009; Xie and Breen, 2014; Chen et al., 2019). Specifically, the identified gap in the literature, where academics and practitioners question and argue whether innovative initiatives can be adopted and implemented within the highly complex pharmaceutical delivery system, has been recognised (e.g. Westrick and Mount, 2009; Bhakoo et al., 2012; Narayana et al., 2014; Bravo and Carvalho, 2015; Campos et al., 2017; Lima et al., 2018; Papalexi et al., 2020). Innovation is understood from the definition of Freeman et al. (2006) who indicates that in order for an intervention to be innovative, it must change the systems of production and characteristics of an organisation, in other words the operationalisation.

Addressing this research gap, this study aims to provide additional theoretical and practical insights to the medicine delivery practices, which will have potential implications for supply chain theory and practice. It is concerned with investigating the nature of this phenomenon through assessing the innovativeness of the current delivery processes taking place within the downstream domain of the PSC employed in two diverse European contexts: the UK and Greece. Existing literature mainly focused on the upstream domain of the PSC that includes the pharmaceutical manufacturers (e.g. Danese, 2006; Narayana et al., 2014). This study, therefore, contributes to the need for exploring the PSC downstream domain, which has been reported in the current literature (e.g. Narayana et al., 2014; Bam et al., 2017; Campos et al., 2017; Dobrzykowski, 2019). Moreover, it will assess how the adoption of innovative approaches, such as Lean Philosophy (Randor and Barnes, 2007), Reverse Logistics (RL) (Defee et al., 2009; Kumar et al., 2009, Breen and Xie, 2015) 
and Information Technology (IT) systems, can overcome supply chain operational inefficiency, while optimising the PSC downstream network. The lack of focus on the combination of innovative approaches that are considered as the most effective ways to manage the PSC has been emphasised in the literature (e.g. Kang Sherman Heng and Loosemore, 2013; Campos et al., 2017). Our paper attempts a contribution that is both rigorous and relevant (Hodgkinson and Rousseau, 2009) by considering both a theoretical and practical problem when formulating the research questions and positioning the contributions (Nicholson et al., 2018). According to Nicholson et al.'s (2018) contribution conceptual framework, this paper makes an incremental contribution, which is measured against what knowledge already exists and by developing further what is currently known. Indeed, Cheng et al. (2009) suggested that fruitful theoretical and practical insights are generated by interdisciplinary research. To the best of our knowledge, this multimethod research is underrepresented in the PSC literature.

This paper is structured as follows: the next section presents the relevant literature, arguing that innovation could act as a catalyst in improving PSC efficiency. Then, in the methodology section, the research approach adopted to explore the subject under investigation is presented. Subsequently, the findings detail the current medicine delivery practices undertaken in both the UK and Greece and outline the identified factors that support or prevent innovative programmes that can be applied within the downstream domain of the PSC. The discussion section highlights the contribution of the study, providing additional theoretical and practical insights to highly complex PSC. The final section reports the conclusions and limitations of the study.

\section{Literature review}

The need for improving the production of healthcare services with respect to the quality of service, patient safety and satisfaction, and the cost of care is now widely accepted (Dobrzykowski, 2019). The increased pressure on healthcare organisations to reduce their pharmaceutical spending converts 
this need into a crucial one (Lainez et al., 2012; Al-Balushi et al., 2014). It is believed that the effective management of the PSC could minimise the perceived waste and associated costs, as well as enhancing service quality (Breen and Xie, 2015; Altug and Sahin, 2019; Papalexi et al., 2020). It is envisaged that these could be attained by adopting innovative approaches in the pharmaceutical supply chain process, and by exploring the integration of lean thinking, reverse logistics and information technology from a theoretical standpoint.

Academic literature focusing on the PSC indicates that the application of innovative tools and techniques reduces pharmaceutical waste and enhances the quality of healthcare services (e.g. Breen and Xie, 2015; Pohjosenperä et al., 2018), improves the effectiveness of inventory control (e.g. Pereira et al., 2014; Bam et al., 2017), increases firm innovativeness (e.g. Gölgeci and Ponomarov, 2015; Papalexi, 2017), enhances information reliability (e.g. Chowdhury and Quaddus, 2016) and organisational performance (e.g. Birkie et al., 2017; Chen et al., 2019). In a similar vein, from a practical perspective, reports have been published by healthcare institutes, such as the Department of Health and Social Care (UK) and the National Organisation for Medicines (Greece) which aim to guide healthcare organisation on how best to implement innovative approaches to improve the delivery of medicines (DHSC, 2019; NOfM, 2016). However, implementing innovation within the PSC is not yet adequate; at present there appears to be a lack of experience and knowledge of how such initiatives should be implemented (Narayanamurthy et al., 2018).

\subsection{Innovation in the PSC}

Scholars exploring the PSC highlight the benefits generated by adopting innovation. Theoretical innovations such as Lean thinking (Burgess and Radnor, 2013; Baker, 2014), along with technological innovations such as 'Radio Frequency Identification' (RFID) (Wamba et al., 2013; Shafique et al., 2019) and the development of information technology (IT) (Cranfield et al., 2015) are being implemented throughout the Pharmaceutical Supply Chain (PSC). Initial interventions have focused on applying Just-In-Time (JIT) approaches (Braga et al., 2015) and inventory control systems 
such as Vendor Managed Inventory (VMI) (Mustaffa and Potter, 2009; Bhakoo et al., 2012); Weraikat et al. (2019) used VMI to explore the quality of expired medications at hospitals. The application of Lean Philosophy and Reverse Logistics (RL) has been suggested as a solution to reduce preventable pharmaceutical waste and increase the quality of healthcare services (Kumar et al., 2009; Breen and Xie, 2015), but more evidence will be necessary to support this approach. Kumar et al. (2009) analysed the pharmaceutical supply chain using the Define, Measure, Analyse, Improve and Control (DMAIC) process for improvement of reverse logistics. They found that specific information on the Pharmaceutical Supply Chain was limited because the majority of the reverse logistics for pharmaceuticals is handled through third-party providers. Papalexi et al. (2015) focused on the implementation of the kanban system on the supply chain for a group of cooperative pharmacists proposing that the organisation can store $56.8 \%$ fewer products and spend $71.8 \%$ less money, by adopting the kanban system. Simulation modelling and outsourcing of noncritical medical supplies were examined by scholars such as Battini et al. (2013) and Franco (2018), aiming at reducing inventory costs without influencing the quality of services. Danese (2006) suggested the use of Information Technology (IT) across the network for sharing and exchanging information and highlighted the significance of trust within it. According to Raghupathi and Raghupathi (2014), there is a potential to improve care, save lives and lower costs through identifying associations and understanding patterns and trends within the healthcare data.

\subsection{Barriers to innovative uptake and implementation}

Although innovation within healthcare attracts scholars' interest, reviews of healthcare reforms and performance have confirmed that innovation in the healthcare sector is considered to lag behind that of non-healthcare sectors (Bhakoo et al., 2012). Studies have concluded that the PSC's complexity is the reason for the sector's difficulties in adopting innovative approaches (Williams, 2011). Several factors contribute to the complexity of the PSC, as reported by Xie and Breen (2012), Bhakoo et al. (2012), and Papalexi et al., 2020 among others. Initially, the complexity of the delivery system is 
increased due to the involvement of numerous stakeholders within the PSC that have diverse roles and responsibilities (de Vries and Huijsman, 2011). Actors of the PSC tend to operate independently and any change that might impact upon their role could be perceived as a threat (Burnes and Jackson, 2011). Individual perspective, attitude and knowledge are likely to influence the success rate of innovation (Greenhalgh et al., 2012). In addition, a high level of trust and information sharing is often difficult to achieve within systems where myriad actors are involved; the success of innovative interventions relies on such ingredients (Simchi-Levi et al., 2008). Therefore, observing the pharmaceutical supply chain from a system complexity perspective (Blackhust et al., 2004) is deemed appropriate in the context of this research.

Furthermore, forecasting as part of information technology and reverse logistics dimension, is proven to be a challenging process for pharmacies because, on one hand, pharmaceutical products are stored in several areas throughout the PSC (Mustaffa and Potter, 2009) generating a number of inventory points that all need to be clearly captured by an integrated information system and, on the other hand, there is a high level of demand variation (Danas et al., 2006) that indicated the dynamic aspects within this complex system. The unpredictable demand does not support the push logistics practices that are currently employed and, as a result, high levels of safety stock are put in place to ensure the products' availability (Bhakoo et al., 2012), therefore avoiding stock-outs on critical products. Considering that medicines are relatively sensitive and expensive products, carrying safety stock increases the likelihood that these products will expire and more waste will be generated, which affects the population's health and the ecological environment (Wang et al., 2015). Therefore, adopting innovative processes in order to monitor products and their safety stock by using an integrative information system, avoid waste by implementing and considering lean principles, and bring back products in the supply chain has the potential to generate value to PSC.

Interestingly, the existence of institutional and regulatory pressures might prevent the adoption and diffusion of innovation (Shah, 2004). Narayanamurthy et al., (2018) stated that healthcare organisations are considered to be relatively centralised. Within functionally centralised 
organisations, the process of implementing innovative programmes might be ineffective or considerably slow (Bamford et al., 2015).

In addition, healthcare professionals have limited knowledge of innovation and the existing information on this is not always accessible, especially in the area of organisational and process innovations (Grol and Wensing, 2004; Greenhalgh et al., 2012). As a result, there is a shortage of expertise and methods, which means that healthcare professionals find it difficult to support such implementations. The lack of experience might lead to adoption of incorrect methods or the suboptional use of the existing guidance, which explains why this sector is behind in adopting and implementing effective Supply Chain management (SCM) approaches (Bhakoo et al., 2012). Finally, the limited financial resources available and the lack of Supply Chain Management (SCM) knowledge can act as obstacles when attempts at implementing innovative healthcare initiatives are undertaken (e.g. Davies and Edwards, 2013).

Figure 1 presents the complexity of the PSC by adapting the fundamental operations system. This was developed based on the literature detailed above. This was adopted because it is an effective and simple way to describe the production of a process, in this case the process is the delivery of medicines. It provides information about the inputs that a production of a process requires, the elements included during the production and the outputs of a process. Particularly, Figure 1 considers as inputs the different groups of stakeholders involved within the PSC, such as pharmaceutical companies, wholesalers, suppliers, the Government and communities; each having a different role that influences the delivery of medicines. In Figure 1 there is an arrow showing that the inputs contribute to the production of the process. There are also many elements that affect the production phase of healthcare services as noted in Papalexi (2017), such as distribution networks, inventory management, demand and availability of products, transportation, global movement, drug research and development, illness, population growth and quality of life, treatment and drug prescription and others, which might impact upon the delivery process and as a result the quality of healthcare services that the customers (outputs) receive. As Figure 1 illustrates, the production of the delivery process 
links (using an arrow) to the outputs of the process; in this case, the areas that the medicines are delivered/consumed, such as hospitals, pharmacies, patients and society. PSC literature indicates that a number of challenges need be addressed in order for the medicine delivery system to be improved. These are related to the high cost of services, lack of finance, high level of wastage, lack of transparency and visibility, lack of communication, lack of information and knowledge and even lack of strategy (Mustaffa and Potter, 2009; Bhakoo et al., 2012; Xie and Breen, 2012; Papalexi et al., 2020). Every time that a delivery process is completed, those challenges have to be considered in order for the next delivery process to be improved, as Figure 1 presents.

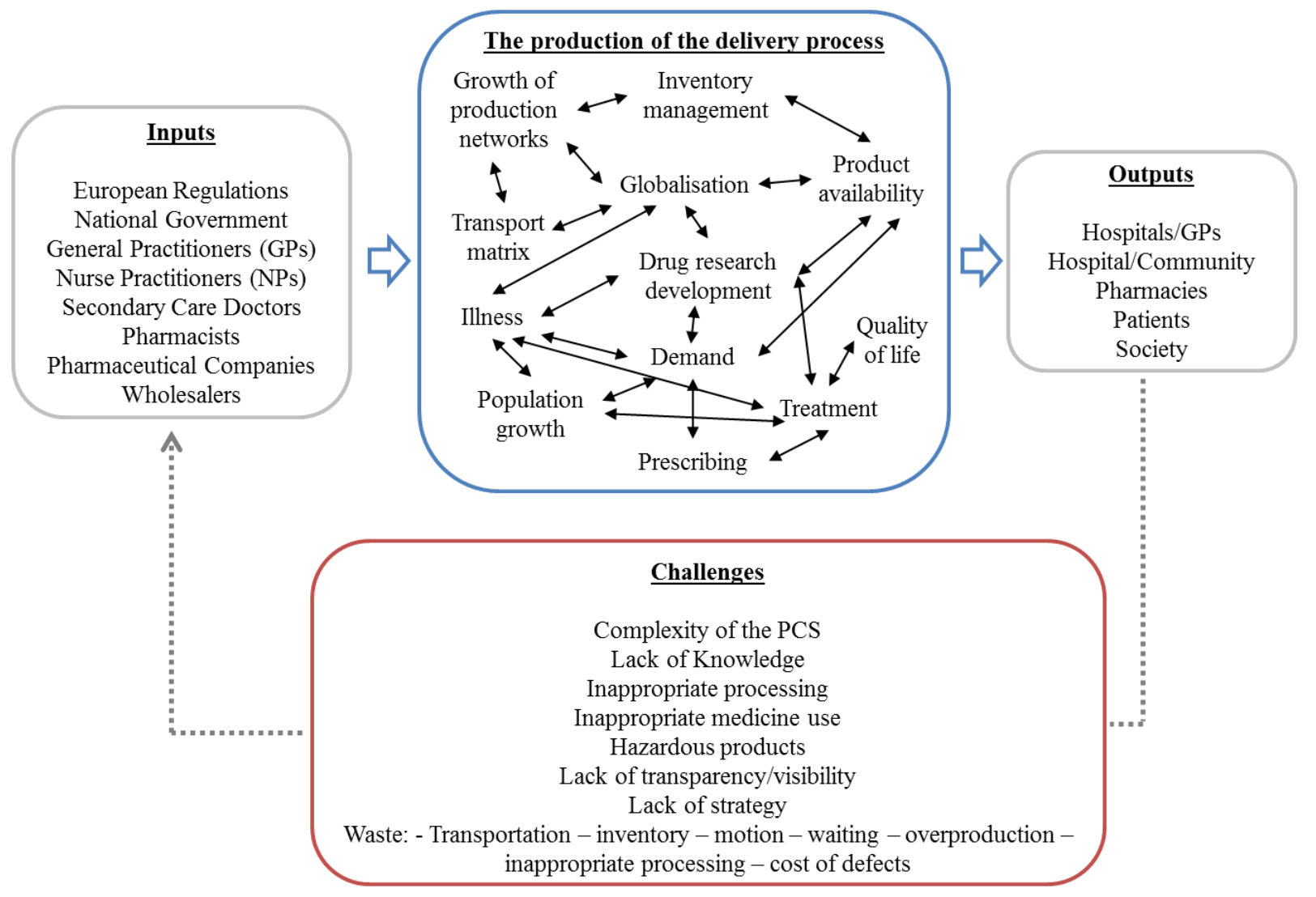

Figure 1: A fundamental model of the Pharmaceutical Supply Chain and Society

\section{Research Methodology}

\subsection{Research Context}


This exploratory research adopts a mixed-method approach, aiming to investigate aspects of innovation within the complex PSC environment and in particular the impact of innovation on the medicine delivery process employed within the downstream domain of the PSC in the UK and Greece. A mixed-methodology has rarely been used before for examining PSC-related research (Narayana et al., 2014) despite its potential to serve for the mutual validation of data and findings, as well as for the production of a potentially more coherent and complete picture of the investigated domain than mono-method research can yield (Kelle, 2006). The selection of these particular countries was deliberate, as it has been demonstrated that region-dependent environmental and organisational influences have affected the pharmaceutical delivery systems. For example, although the two selected countries have to follow the same European legislation regarding the management of pharmaceuticals (EMA, 2014), their different healthcare system structures impact upon the PSC's effectiveness. In addition to this, in the era of the global financial recession, the scars of the crisis are more prominent in Greece than in the UK, which might cause particular effects in terms of capacity and resources. In 2018 , the UK spent $\$ 4,070$, per capita while $\$ 2,238$, per capita was allocated to healthcare spending in Greece (OECD Health Data, 2019). However, Greece spent proportionally more on pharmaceuticals as a share of GDP (26.3\% health expenditure, in 2017$)$ than the UK (11.4\% health expenditure, in 2017) (OECD Health Data, 2019).

The two healthcare systems are also different per se. The UK one places more emphasis on developing the primary healthcare settings to promote health and deal with disease at an early stage (Lionis et al., 2009). The Greek healthcare system focuses more on curative services (Souliotis and Lionis, 2005). This is supported by the fact that the share of public resource that is spent on healthcare in the UK $(\$ 3,138 / 77.1 \%)$ is greater than that in Greece $(\$ 1,342 / 59.9 \%)$ (OECD Health Data, 2019). In addition to this, the Greek healthcare system involves a higher ratio of physicians (6.2 per 1000 inhabitants, in 2018) and a lower ratio of nurses (3.3 per 1000 inhabitants, in 2018) than the UK healthcare system (2.9 physicians per 1000 inhabitants; 7.8 nurses per 1000 inhabitants) (OECD Health Data, 2019). 
This research investigates the UK PSC as a whole because pharmacy practice throughout the UK is very similar with some local variations due to local management/devolution. For example, Northern Ireland has its own Pharmaceutical Society, which advises and regulates the profession whereas England, Scotland and Wales are regulated by the General Pharmaceutical Council (Great Britain) and advised by the Royal Pharmaceutical Society of Great Britain and other pharmacy membership organisations. Pharmacists receive the same professional training so they can practice across these locations (GPhC, 2011). Services offered within hospital and community pharmacies are similar.

Our aim is to investigate the complex pharmaceutical delivery process adopted and applied within the two diverse contexts; thus the reason for choosing the UK and Greece PSCs. This approach enabled the identification of similarities and differences between the two delivery systems and helped improve and expand our understanding of the PSC downstream domains beyond the context of a single country.

Data was collected from both hospital and community pharmacies. Hospital pharmacies generally are more removed from the patient within their local community by their placement and role within the supply chain. Due to the nature of hospital services and resource availability there is a higher expectation of hospital pharmacies to source materials quickly especially in cases of emergencies or product shortages. As hospitals are vanguards of service delivery, pharmacy services will be more advanced than community pharmacy. There will be greater ICT innovation in relation to access to patient records, transfer of discharge records and medicines to GPs and community pharmacies (Galloway, 2021). Traditionally community pharmacists have a more restricted diet of activity as standard (mainly dispensing of medicines) but have extended this offering to include more service innovations such as medicines use consultations, public health awareness, health promotion etc (Baird and Beech, 2020).

\subsection{Research Design}


This study adopted an exploratory mixed-method design to address the research questions. Specifically, the qualitative data collected via unstructured interviews helped the authors build an initial in-depth understanding of the elements defining the downstream PSC delivery. The survey went a step further and was more innovation-centric per se so that complementary results looking at various facets of the studied phenomenon could be generated as Golicic and Davis (2012) have reported. Fawcett and Magnan (2002, pp.343) suggested that "combining surveys with interviews in a complementary research design yields a rich and robust view of modern supply chain integration practice from different points of view" something that we adopted. This mixed-method approach is also in line with previous studies (e.g. Feldon and Kafai, 2008; Creswell and Plano Clark, 2011). A representative example of a healthcare study is Schadewaldt et al. (2014); the study focused on human factors trying to identify the characteristics of collaboration between nurse and medical practitioners in the primary healthcare sector.

\subsubsection{Exploratory Design}

The exploratory sequential design commences with the qualitative strand of activity, which aims to appreciate the context and its singularities. An in-depth understanding of professionals' views and experiences was vital for developing an initial understanding of the current pharmaceutical delivery system applied in the UK and Greece. This allowed us to develop the complementary (to the qualitative findings) direction, content and nature of the survey instrument; the survey questions (see Appendix) concentrate on areas that were not entirely covered by the qualitative themes and expanded the study's focus to a more direct innovation-based context. This 'feeding' approach supported by the use of our mixed method research design improved the holistic character of the study.

The quantitative approach was adopted as a follow-up to the qualitative work, to gain 'more measurable' results that could more accurately describe the phenomenon under investigation and offer statistical results. While the qualitative work helped the identification of the key building blocks of the overall procedure the survey entered more explicitly the innovation parameter per se. The 
questionnaire was distributed to hospital and community pharmacy professionals working within the downstream domain of PSC in the UK and Greece. The Total sample $(\mathrm{N}=130)$ consisted of 81 hospital and community pharmacies working within the PSC in Greece and 49 pharmacy specialists who operate in the UK. The collection of the quantitative data enabled us to identify the factors that influence the innovation level of the current delivery process and to suggest alternative solutions to improve this process for the benefit of stakeholders and patients. Figure 2 illustrates the methodological framework of the present study.

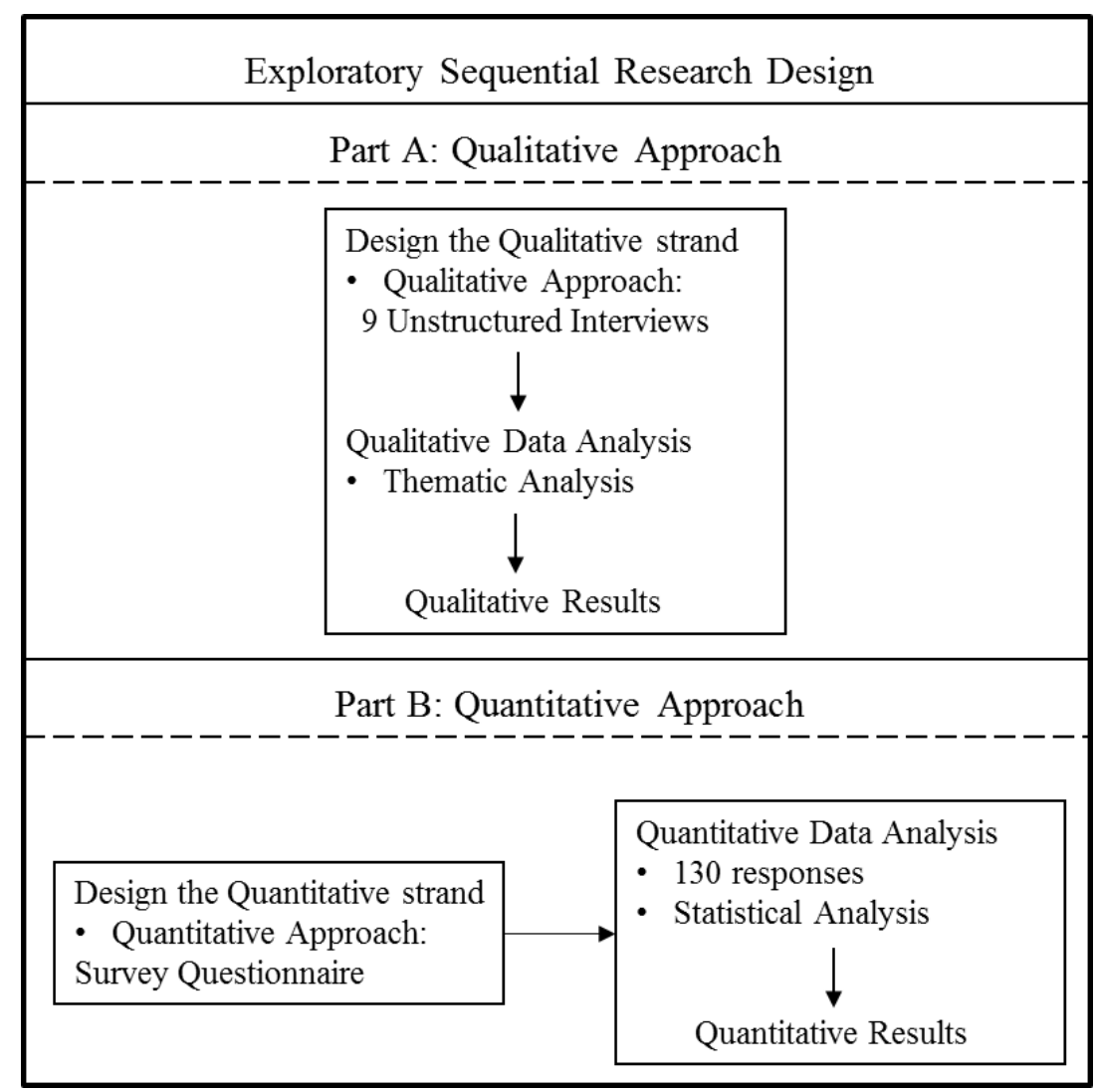

Figure 2: The Research Design Adopted

\subsection{Data collection, sample population and data analysis}

\subsubsection{Qualitative approach}

The qualitative data were collected via a series of site visits and one-to-one unstructured interviews with key pharmacy professionals working in hospital and community pharmacies in the UK and Greece. This approach was adopted, on one hand, to form a more comprehensive view of the current 
medicine delivery process and, on the other hand, as a process supporting the content and direction of the survey. In total, nine unstructured interviews lasting two hours on average were undertaken: five in the UK and four in Greece. The interviews provided enough data to cover the research content; the authors stopped when the saturation level was reached meaning that the process was becoming repetitive (O'Reilly and Parker, 2012). Each interview was audio-taped and transcribed verbatim. Table 1 presents key interviewee characteristics aiming to provide information related to their background, which potentially influence their views regarding the study subject, for example the key question presented in the final column (supply chain operation innovativeness) were only two believed innovation existed. A challenge with the research is understanding the context of their response on aspects of innovation.

Table 1: Participants' Characteristics

\begin{tabular}{|c|c|c|c|c|c|}
\hline \# & Reference & Gender & Position & $\begin{array}{l}\text { Working } \\
\text { Experience }\end{array}$ & $\begin{array}{l}\text { Supply chain } \\
\text { operation } \\
\text { Innovativeness }\end{array}$ \\
\hline 1 & 1/UK & $\mathrm{F}$ & Lead hospital Pharmacist & 12 Yrs & Unsure \\
\hline 2 & 2/UK & M & Chief community Pharmacist & 8 Yrs & Unsure \\
\hline 3 & 3/UK & M & Chief community pharmacist & 6 Yrs & $\begin{array}{c}\text { Yes, the supply } \\
\text { chain operation is } \\
\text { innovative }\end{array}$ \\
\hline 4 & 4/UK & M & $\begin{array}{l}\text { Procurement and Homecare } \\
\text { Manager (hospital pharmacist) }\end{array}$ & 7 Yrs & $\begin{array}{l}\text { No, the supply } \\
\text { chain operation is } \\
\text { not innovative }\end{array}$ \\
\hline 5 & $5 / \mathrm{UK}$ & $\mathrm{F}$ & $\begin{array}{c}\text { Chief hospital Pharmacy } \\
\text { Technician }\end{array}$ & 2 Yrs & $\begin{array}{c}\text { Yes, the supply } \\
\text { chain operation is } \\
\text { innovative }\end{array}$ \\
\hline 6 & $6 / \mathrm{Gr}$ & M & Community Pharmacist & 11 Yrs & Unsure \\
\hline 7 & $7 / \mathrm{Gr}$ & M & Hospital Pharmacist & 13 Yrs & $\begin{array}{l}\text { No, the supply } \\
\text { chain operation is } \\
\text { not innovative }\end{array}$ \\
\hline 8 & $8 / \mathrm{Gr}$ & $\mathrm{F}$ & Community Pharmacist & 22 Yrs & Unsure \\
\hline 9 & $9 / \mathrm{Gr}$ & $\mathrm{F}$ & Hospital Pharmacist & 15 Yrs & $\begin{array}{l}\text { No, the supply } \\
\text { chain operation is } \\
\text { not innovative }\end{array}$ \\
\hline
\end{tabular}


In this research, the target sample involves professionals working in hospital and community pharmacies in two diverse geographical areas: Greece and the UK. This research aims to explore how innovative programmes could improve the downstream domain of the PSC which is directly related to patients, identifying the related issues. This study adopted a purposive sampling technique (Tongco, 2007) in order to address the research aim, therefore, only those specialists who work within this domain could be considered as potential participants. The exact number of pharmacists that operate within the particular study area is not available. However, according to Eurostat (2018) statistics 104.9 per 100,000 inhabitants was the number of professionally active pharmacists in Greece and 86.2 per 100,000 inhabitants in the UK.

During the qualitative data collection, the authors faced difficulties in approaching the potential interviewees. They were very cautious about being involved in this research, mainly because they thought that their role was not related with Operations Management (OM) or Supply Chain Management (SCM) practices. They were, therefore, excluded due to concerns related to the minimum knowledge about these particular practices and organisational performance (e.g. Nulty, 2008). In addition to this, some of the potential participants were reluctant to take part in this study because of their heavy work load. The authors approached only those specialists that could be reached in terms of geographical distance. Although the described issues illustrate the magnitude of the challenge faced, finally, 9 unstructured in-depth and lengthy interviews were undertaken that provided data to address the aims of this research.

The qualitative data were thematically analysed; thematic analysis has been widely used as a foundational method for analysing qualitative data (Guest et al., 2012). Themes organise a group of repeating ideas, which allows researchers to answer the research questions (Vaismoradi et al., 2016). There are numerous reported articles referring to thematic analysis agreeing that there is no right or wrong way to conduct it (Vaismoradi et al., 2016). In this research, the analysis of the research interviews was conducted using Braun and Clarke's (2013) linear model for carrying out thematic analysis as adapted by Nikitas et al. $(2018 ; 2019)$. This model includes six procedural steps: i) 
Familiarisation with the data; ii) Generation of initial codes; iii) Searching for themes; iv) Reviewing themes; v) Defining and naming themes; and vi) Producing the final report. This process was influenced by the presented conceptual framework, deductively informed by the literature review and guided by the authors' specific research interest.

\subsubsection{Survey approach}

A quantitative survey was employed to: i) capture the level of innovation applied during the delivery of medicines; and ii) identify the factors that influence positively or negatively the decision of hospital and community pharmacies to innovate. A mail type and a web type questionnaire survey were used for this research to raise the response rate and reduce the collection time (Groves et al., 2011). Considering that the survey was distributed to professionals working within the PSC in the UK and Greece, two different versions were created to ensure that the respondents could accurately understand the survey and provide answers that best represent their views (Cha et al., 2007). The questionnaire was initially developed in English and then translated to Greek. Particularly, the back translation technique was adopted, which involves two translation processes: i) initially the questionnaire was translated from the source language (English) into the target language (Greek) by a translator; then ii) the Greek version (target language version) was translated back into the English version (source language version) by another translator; and finally the two different versions were compared (Maneesriwongul and Dixon, 2004).

The respondents were asked questions related to factors supporting innovation (reduced time to respond to customer or supplier needs; improved staff communication; enhanced staff or patient satisfaction), factors preventing innovation (excessive perceived economic risks; direct innovation costs too high; lack of finance), access to information, external/internal collaboration, innovation level regarding the use of technology and innovation level regarding the introduction of new/improved products/services. These particular topics clearly add to the innovation parameter in the present research, building on the results of the thematic analysis of the work's qualitative phase where the key elements of the downstream PSC delivery were first identified and contextualised. The 
questions employed in the survey used multiple-item and single-item Likert-type scales. The authors employed 5-point Likert scales with a neutral mid-point. According to Dawes (2008), this is the optimal choice; they are as precise as 7-point Likert scales, but less cognitively challenging. Please see Appendix 1 for the full version of the questionnaire and Appendix 2 for the measurement items for study constructs.

As a snowball sampling technique was used, using the nine interviewees as propagators of the survey participation call, and since the questionnaire was mainly distributed through mail accounts and web accounts, the actual response rate is difficult to indicate. This is one of the disadvantages of this distribution strategy, but with a sample so specific and confined this was the only viable approach. The final sample $(\mathrm{N}=130)$ consisted of 81 specialists working within the PSC in Greece and 49 specialists located in the UK. Table 2 summarises the sample size and its key characteristics.

Table 2: The sample size and characteristics

\begin{tabular}{|c|c|c|c|c|c|c|c|}
\hline & \multirow{3}{*}{$\begin{array}{c}\text { National } \\
\text { Context }\end{array}$} & \multirow{3}{*}{$\begin{array}{c}\text { Sample } \\
\text { Size }\end{array}$} & \multicolumn{5}{|c|}{ Sample Characteristics } \\
\hline & & & \multicolumn{2}{|c|}{$\begin{array}{c}\text { Working } \\
\text { Experience }\end{array}$} & \multicolumn{3}{|c|}{ Educational Level } \\
\hline & & & $\begin{array}{c}>15 \\
\text { Years }\end{array}$ & $\begin{array}{l}<15 \\
\text { Years }\end{array}$ & $\begin{array}{l}\text { Professional } \\
\text { Qualification }\end{array}$ & $\begin{array}{c}\text { Bachelor's } \\
\text { Degree }\end{array}$ & $\begin{array}{c}\text { Postgraduate } \\
\text { Degree }\end{array}$ \\
\hline $\begin{array}{c}\text { Total } \\
\text { Sample }\end{array}$ & $\begin{array}{c}\text { Greece + } \\
\text { UK }\end{array}$ & 130 & $68 \%$ & $32 \%$ & $18 \%$ & $69 \%$ & $13 \%$ \\
\hline $\begin{array}{c}\text { Greek } \\
\text { Sample }\end{array}$ & Greece & 81 & $62 \%$ & $38 \%$ & $6 \%$ & $94 \%$ & - \\
\hline $\begin{array}{c}\text { UK } \\
\text { Sample }\end{array}$ & UK & 49 & $78 \%$ & $22 \%$ & $37 \%$ & $36 \%$ & $27 \%$ \\
\hline
\end{tabular}

Two types of statistical techniques were adopted: descriptive and regression analyses. A Linear Regression Analysis (LRA) was conducted to assess the relationships between all pairs of variables in the study (Gravetter and Wallnau, 2011) followed by a multi-group regression.

\section{Findings - Qualitative and Quantitative Data Analysis}

\subsection{Describing the downstream delivery process: a qualitative approach}


The qualitative data analysis highlighted key areas that describe the current pharmacy delivery practices in the UK and Greece, including: outbound operations (the supply routes), Inbound operations (delivery processes), inventory management and the perceived level of system wastage. Table 3 presents these themes using raw quotes provided by the interviewees; care was taken to accurately present the most representative interviewee insights instead of centring this analysis on our own interpretations thus reducing analyst bias. 
Table 3: The emerged themes with evidence from the interviews

\begin{tabular}{|c|c|c|}
\hline \multirow{2}{*}{ Themes } & \multicolumn{2}{|c|}{ Example quotations } \\
\hline & Hospital pharmacies & Community pharmacies \\
\hline $\begin{array}{l}\text { Outbound } \\
\text { operations (or } \\
\text { 'supply routes') }\end{array}$ & $\begin{array}{l}\text { Three different supply routes } \\
\text { 1. Medication for general use (stored in the wards' cupboards) } \\
\text { 2. Medication issued for a particular patient (stored in the box next to } \\
\text { the patient's bed) } \\
\text { 3. The discharged medication (used at home) } \\
\text { - "doctors on wards prescribe medication electronically [...] } \\
\text { Subsequently, the prescription can be either checked by a } \\
\text { pharmacist on the ward or in the dispensary and then we print it } \\
\text { off and complete the prescription" (1/UK) } \\
\text { "we still deliver medication using a paper-based process. } \\
\text { Electronic prescription has been introduced and even used in some } \\
\text { hospitals but the problem that we face is that doctors do not have } \\
\text { time to spend on electronic prescription" (9/Gr) }\end{array}$ & $\begin{array}{l}\text { One type of supply route } \\
\text { - "our main concern is about the availability and quality of } \\
\text { drugs [...], we can manage both of them quite well" } \\
(3 / \mathrm{UK}) \\
\text { - "it is a routine process [...] our only challenge is to } \\
\text { understand what is written on the prescription [...]. The } \\
\text { electronic prescription has solved this problem but we } \\
\text { still have to decode some of them which are handwritten" } \\
(8 / \mathrm{Gr})\end{array}$ \\
\hline $\begin{array}{l}\text { Inbound } \\
\text { operations (or } \\
\text { 'delivery } \\
\text { processes') }\end{array}$ & $\begin{array}{l}\text { Hospital pharmacies in the UK and Greece tend to order the required } \\
\text { products five days per week, twice a day. } \\
\text { - "wholesalers deliver items twice a day, every day and we } \\
\text { sometimes receive an order on Saturday morning [...], so we } \\
\text { usually have ten or eleven deliveries from each wholesaler per } \\
\text { week" }(1 / \mathrm{UK}) \\
\text { - "the delivery process would depend on how frequently we need the } \\
\text { products and the agreement that we have set up with our } \\
\text { suppliers" }(7 / \mathrm{Gr}) \\
\text { - "approximately } 90 \% \text { of the required products are delivered } \\
\text { through wholesalers, however, there are pharmaceutical } \\
\text { companies that prefer to supply the required items directly to } \\
\text { pharmacies" }(9 / \mathrm{Gr})\end{array}$ & $\begin{array}{l}\text { Community pharmacies receive the majority of required products } \\
\text { from one main wholesaler and some from pharmaceutical } \\
\text { companies. Community pharmacies in the UK normally receive } \\
\text { medicines two times per day and they can easily deal with an } \\
\text { emergency because the warehouse is located close to them. } \\
\text { - "community pharmacies in the UK tend to be big } \\
\text { companies having many stores all over the country, such } \\
\text { as Boots and Lloyds; they run their own warehouse, so } \\
\text { they have better control of the products that they manage" } \\
\text { (3/UK) } \\
\text { Community pharmacists in Greece have their own store but they } \\
\text { tend to cooperate; there are } 27 \text { organisations founded by a group } \\
\text { of cooperative pharmacists which are responsible for the smooth } \\
\text { and regular supply of pharmaceuticals and paramedical products }\end{array}$ \\
\hline
\end{tabular}




\begin{tabular}{|c|c|c|}
\hline & $\begin{array}{l}\text { - "hospitals sign up contracts with their suppliers, which enable them } \\
\text { to receive the medicines at better prices and also build a } \\
\text { relationship with them which, at some point, ensures the quality } \\
\text { and on time delivery" }(4 / \mathrm{UK}) \\
\text { Hospital pharmacies order the items using an online system. } \\
\text { - "the information system that we use enables us to check our stock } \\
\text { level, create the next order, calculate the cost and send the order } \\
\text { to our suppliers" }(4 / \mathrm{UK}) \\
\text { - "the information system enables us not only to check and order } \\
\text { stock but also inform them about any type of changes, such as cost } \\
\text { or stock changes" ( } 7 / \mathrm{Gr})\end{array}$ & $\begin{array}{l}\text { to the pharmacies operating in the same geographical area - there } \\
\text { are approximately } 6,000 \text { associate member pharmacies. } \\
\text { " we are quite satisfied with the foundation of such an } \\
\text { organisation; it works like a wholesaler for us and we } \\
\text { order more that } 90 \% \text { of the required medicines from it } \\
\text { [...]we are able to receive items five or six times per day; } \\
\text { we can have them within an hour of the order" }(6 / \mathrm{Gr}) \\
\text { Community pharmacies in both countries order the required } \\
\text { products using an online system that is similar to that used by the } \\
\text { hospital pharmacies, albeit more developed. }\end{array}$ \\
\hline $\begin{array}{l}\text { Inventory } \\
\text { Management }\end{array}$ & $\begin{array}{l}\text { To ensure the availability of medicines and minimise the risk of them being } \\
\text { out of stock, hospital pharmacies have an average of two weeks' stock and } \\
\text { stock check them frequently. } \\
\text { - "according to our national guidance, we have to store some } \\
\text { medicines, such as some antidotes for poisoning [...], but generally } \\
\text { we keep two weeks' safety stock" }(5 / \mathrm{UK}, 9 / \mathrm{Gr}) \\
\text { - "we do stock check the whole stored supply during the year to } \\
\text { minimise the risk of the medicines being out of date" ( } 7 / \mathrm{Gr}) \\
\text { - "once the stock check has been done, if we discover that there are } \\
\text { some short dated items we can swap them with other medicines } \\
\text { from the Co-operative pharmacy; we have set up an agreement with } \\
\text { the Co-operative pharmacy which helps us to reduce the waste of } \\
\text { 'unused' medicines" (1/UK). This type of agreement does not exist } \\
\text { in the Greek system. }\end{array}$ & $\begin{array}{l}\text { Community pharmacies in both countries do not tend to keep } \\
\text { safety stock because they are able to order and receive medication } \\
\text { immediately } \\
\text { - "We just keep enough quantities of the medicines that we } \\
\text { sell more frequently" }(8 / \mathrm{Gr}) \\
\text { - "there is no need for keeping safety stock [...], we keep } \\
\text { two days' stock to ensure that our customers are satisfied } \\
\text { (3/UK) }\end{array}$ \\
\hline $\begin{array}{l}\text { Perceived level of } \\
\text { system wastage }\end{array}$ & $\begin{array}{l}\text { The level of wastage is very high and it mainly occurs at ward level. } \\
\text { - "the ward staff has the responsibility to manage their own stock of } \\
\text { medicines [...] considering that their main focus is to treat patients } \\
\text { properly, they have limited time to focus on stock related issues, } \\
\text { something that in general increases the level of wastage" }(9 / \mathrm{Gr})\end{array}$ & $\begin{array}{l}\text { The level of wastage is not particularly high. } \\
\text { - "the level of wastage is low within the pharmacy because } \\
\text { - we do not really store products" }(8 / \mathrm{Gr}) \\
\text { "we are quite good in managing our products [...]; the } \\
\text { information system that we use informs us about the level } \\
\text { of stock that we have; there is a minimum and maximum }\end{array}$ \\
\hline
\end{tabular}


- "stock checking is not an essential part of the nursing role and they have not been trained to effectively manage stock rotation, hence stockpiling and obsolescence occurs" (4/UK)

Discharge medication issued to wards can be reused.

- "sometimes medication does not follow the patient; we do not waste these medicines; they are returned back to the pharmacy and are reused"( $7 / \mathrm{Gr})$

- "we supply approximately $£ 30$ million of medication per annum of which $£ 36,000$ per annum is returned and reused" (1/UK)

On various occasions, medicines cannot be re-used.

- "a lot of times patients bring their medication with them, if, according to their condition, this medication has to be changed, we are not allowed to use the previous one based on the national guidelines" (9/Gr)

- "there is the guidance from the General Pharmaceutical Council which does not allow us to use any medication issued by a community pharmacy or another hospital [...], this is reasonable because we cannot attest the source and control of it" (1/UK) level of stock and when it gets down to a certain level that is the critical point where we have to re-order" (2/UK)

The biggest amount of waste comes from patients

- "patients have not been educated to bring their spare medication back to the pharmacy; they tend to keep it just in case they need it in the future [...] we are able to collect the unusable medication; there is a DOOP bin in each store where any patient returns or any out of date stock can go into. Subsequently, those medicines are collected and destroyed by the local authority" (3/UK)

- "according to national guidance, each pharmacy has to display a bin for collecting the unused medication. On the one hand it is hard to persuade patients to bring back their spare medicines and on the other hand the local authority does not collect them often" (6/Gr) 


\subsection{Survey Analysis-Level of Innovation within the downstream domain of the PSC}

With the development of an understanding about the key elements of the process from the qualitative phase, measuring the existing level of innovation and identifying the factors that support or prevent innovative programmes that can be applied within the downstream domain of the PSC through LRA, was the follow-up research step taken. The results of this analysis are presented in the following subsection, testing three innovation-focused hypotheses as these have been developed by the authors' literature review, qualitative phase and their parallel research (Papalexi et al., 2020). The hypotheses meant to investigate critical relationships between particular aspects of innovation as expressed by technology uptake and introduction of new/improved products and services and perceived innovation barriers and enablers.

Hypothesis 1(H1): Reduced time to respond to customers/suppliers (a), improved staff communication $(b)$ and enhanced staff/patients' satisfaction $(c)$ are positively related to the innovation level regarding the use of technology $(i)$ and the introduction of new/improved products/services (ii).

Hypothesis 2 (H2): Economic risk (a), cost of innovation (b) and lack of finance (c) are negatively related to the innovation level regarding the use of technology (i) and the introduction of new/improved products/services (ii).

Hypothesis 3 (H3): Access to information (a) and external/internal collaboration (b) are positively related to the innovation level regarding the use of technology (i) and the introduction of new/improved products/services (ii).

\subsubsection{The study variables}

The quantitative analysis contains 10 variables; each of which was operationalised on a 5-point Likert scale. The study variables are presented in Table 4. Variables 2-9 are the independent variables for 
this study. The two dependent variables (10-11) are: the innovation level regarding the use of technology and the innovation level regarding the introduction of new/improved products/services. These are two diverse forms of innovation; however, as was apparent from the qualitative data analysis, there is no clear distinction between them, as input of technology could affect the service outputs. Table 4 also presents key descriptive statistics: means, standard deviations and correlations between the study variables. No concerns are raised regarding common method variance or multicollinearity issues regarding the specific variables in the data set.

Table 4: Means, standard deviations and correlations between the study variables $(N=130)$

\begin{tabular}{|c|c|c|c|c|c|c|c|c|c|c|c|c|c|c|}
\hline & & Mean & $\mathrm{SD}$ & 1 & 2 & 3 & 4 & 5 & 6 & 7 & 8 & 9 & 10 & 11 \\
\hline 1 & $\begin{array}{l}\text { Reduced tim e to respond to } \\
\text { customers/suppliers }\end{array}$ & 4.02 & 1.05 & $.270^{*+}$ & - & & & & & & & & & \\
\hline 2 & $\begin{array}{l}\text { Improved staff patients } \\
\text { communication }\end{array}$ & 3.51 & 1.10 & -.014 & $.383^{*+}$ & - & & & & & & & & \\
\hline 3 & Enhanced staff/patients satisfaction & 3.88 & 1.01 & $.236^{4 *}$ & $.550^{4 *}$ & $.618^{* *}$ & - & & & & & & & \\
\hline 4 & Economic risk & 3.87 & 1.03 & $-.223^{*}$ & .095 & .029 & .037 & - & & & & & & \\
\hline 5 & Cost of innovation & 4.03 & .93 & $-.251^{* *}$ & .040 & -.012 & -.071 & $.759^{4 *}$ & - & & & & & \\
\hline 6 & Lack of finance & 3.96 & 99 & $-.292^{4 *}$ & .023 & .044 & .018 & $.610^{4 *}$ & $.716^{* *}$ & - & & & & \\
\hline 7 & Access to information & 3.59 & .75 & .076 & $.383^{*+}$ & $.445^{*+}$ & $.523^{*+}$ & -.059 & -.167 & -.087 & - & & & \\
\hline 8 & External/internal collaboration & 3.58 & .82 & -.142 & $.182^{*}$ & $.290^{4 *}$ & $.275^{* *}$ & .112 & .069 & -.050 & $.284^{* *}$ & - & & \\
\hline 9 & Innovation L evel- Technology & 4.01 & .85 & .086 & $.269^{* 4}$ & .107 & .159 & .015 & -.050 & -.083 & $.234^{* *}$ & $.297^{* *}$ & - & \\
\hline 10 & $\begin{array}{l}\text { Innovation L evel-New/im proved } \\
\text { products/services }\end{array}$ & 3.51 & .83 & -.062 & .147 & $.268^{* *}$ & $.192^{*}$ & $-.198^{*}$ & -.151 & -.110 & $.299^{* *}$ & $.283^{* *}$ & $.437^{* *}$ & - \\
\hline
\end{tabular}

Note. ${ }^{* *} \mathrm{p}<.01,{ }^{*} \mathrm{p}<.05$

\subsubsection{Linear Regression Analysis}

The results of the LRA, a statistical method frequently used in health care research (e.g. Westrick and Mount, 2009; Boulet et al., 2016), represent the best prediction of how the innovation level applied within the PSC can be influenced by the eight independent variables. Subsequently, a multigroup regression analysis will be presented, aiming to assess and compare the relationship among the study variables in the two different European contexts. Several researchers have adopted this approach when they attempt to compare diverse groups with small, in some cases, sample size (e.g., Esfahbodi et al., 2016; Manning et al., 2016). 


\section{Results in the Total sample: Innovation Level - Technology and New/improved products/services}

According to Hypothesis1, reduced time to respond to customers/suppliers (a), improved staff communication (b) and enhanced staff/patient satisfaction (c) were expected to relate positively to the innovation level regarding the use of technology (i) and the introduction of new/improved products/services (ii). Table 5 indicates that improved staff communication and enhanced staff/patient satisfaction were not significantly related to the innovation level regarding the use of technology and the introduction of new/improved products/services. Therefore, H1bi, H1ci, H1bii and H1cii have been rejected in the total sample. Reduced time to respond to customers/suppliers was significantly and positively related to the innovation level regarding the use of technology, but negatively related to the introduction of new/improved products/services. Based on this result, H1ai has been accepted and $\mathrm{H} 1$ aii rejected in this case.

For Hypothesis 2 assumed that economic risk (a), cost of innovation (b) and lack of finance (c) are negatively related to the innovation level regarding the use of technology and the introduction of new/improved products/services (ii). Table 5 indicates that cost of innovation and lack of finance were not significantly related to the innovation level regarding the use of technology and the introduction of new/improved products/services. Therefore, H2bi, H2bii, H2ci and H2cii have been rejected in the total sample. Economic risk was significantly and negatively related to the innovation level regarding the introduction of new/improved products/services, but it was not related to the innovation level regarding the use of technology. Based on these results, H2aii has been accepted and $\mathrm{H} 2 \mathrm{i}$ was rejected for the total sample.

For Hypothesis 3 to be confirmed, access to information (a) and external/internal collaboration (b) would be positively related to the innovation level regarding the use of technology (i) and the introduction of new/improved products/services (ii). The results indicated that both variables were significantly and positively related to the innovation level regarding the introduction of new/improved products/services. Therefore, H3aii and H3bii have been accepted for the total sample. However, access to information has a non-significant while external/internal collaboration has a significant and 
positive relationship with the innovation level regarding the use of technology. These results indicate the rejection of $\mathrm{H} 3 \mathrm{ai}$ and the acceptance of $\mathrm{H} 3 \mathrm{bi}$ in the total sample.

Table 5: Results of linear regression analysis: Innovation Level - Technology and New/improved products/services $(N=130)$

\begin{tabular}{|l|c|c|c|c|}
\hline \multirow{2}{*}{ Variables } & \multicolumn{2}{|c|}{$\begin{array}{c}\text { Innovation } \\
\text { Level- } \\
\text { Technology }\end{array}$} & \multicolumn{2}{c|}{$\begin{array}{c}\text { Innovation Level } \\
\text { - New/improved } \\
\text { products/services }\end{array}$} \\
\cline { 2 - 5 } & $\boldsymbol{\beta}$ & $\boldsymbol{p}$ & $\boldsymbol{\beta}$ & $\boldsymbol{p}$ \\
\hline Reduced time to respond to customers/suppliers & $\mathbf{. 2 4 0}$ & $\mathbf{. 0 2 6}$ & .048 & .647 \\
Improved staff communication & -.096 & .399 & .113 & .312 \\
Enhanced staff/patient satisfaction & -.076 & .558 & -.031 & .809 \\
Economic risk & .069 & .600 & $\mathbf{- . 2 5 8}$ & $\mathbf{. 0 4 8}$ \\
Cost of innovation & -.139 & .371 & .040 & .792 \\
Lack of finance & .045 & .735 & .027 & .837 \\
Access to information & .140 & .185 & $\mathbf{. 2 1 5}$ & $\mathbf{. 0 3 8}$ \\
External/internal collaboration & $\mathbf{. 2 8 4}$ & $\mathbf{. 0 0 3}$ & $\mathbf{. 2 2 1}$ & $\mathbf{. 0 1 9}$ \\
\hline
\end{tabular}

Results suggest that two factors, reduced time to respond to customers/suppliers and external/internal collaboration, play a significant role in positively influencing pharmacies, operating in both countries, to adopt innovative programmes, specifically through using technology. In addition, economic risk, access to information and external/internal collaboration are the factors that influence pharmacies' decision to introduce new or improved products and services. Figure 3 and Figure 4 below provide the visual representation of the significant and non-significant relationships in the total sample group. 


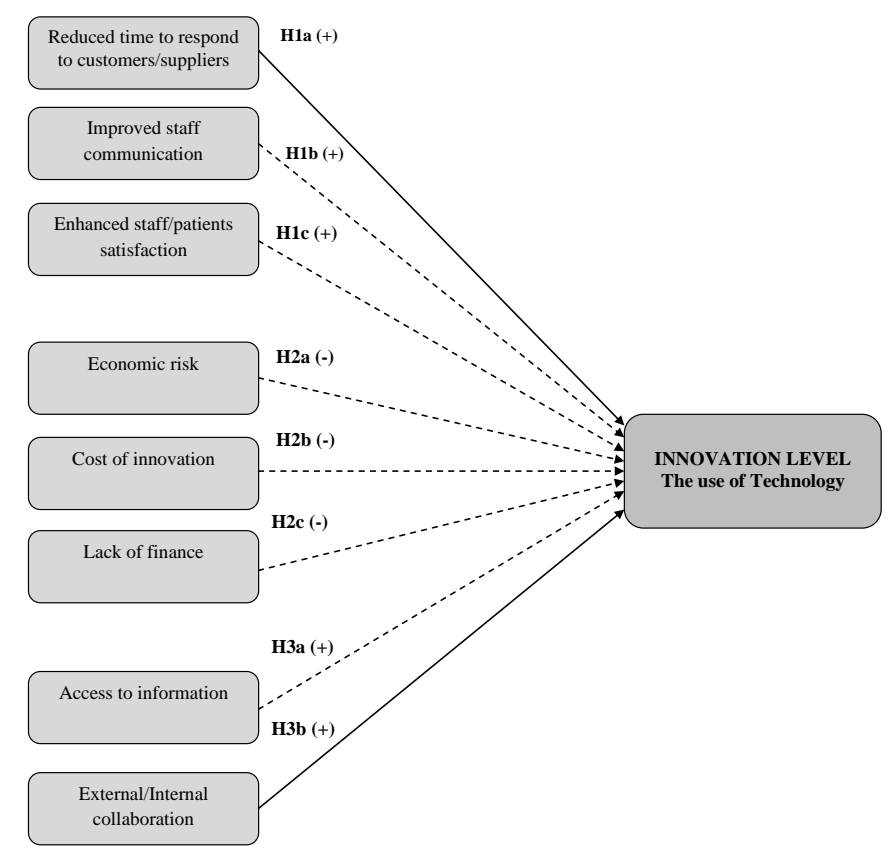

Note. Dashed arrows represent non-significant relationships

Figure 3: Results in the Total sample: Innovation Level-Technology

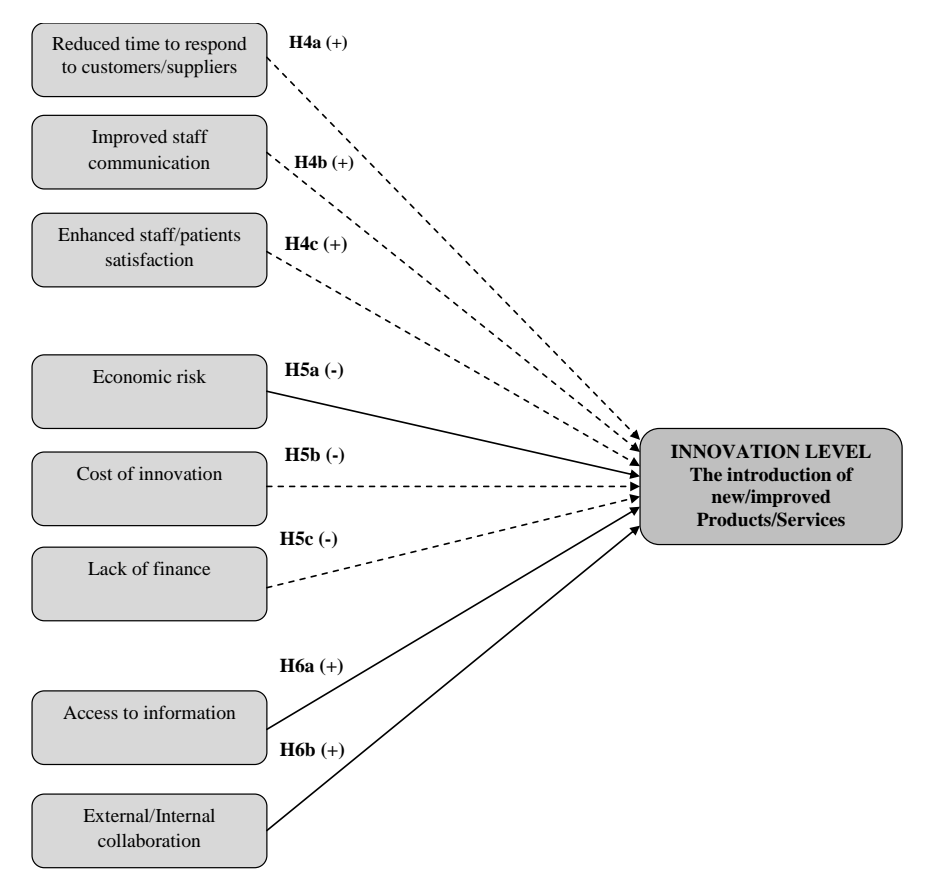

Note. Dashed arrows represent non-significant relationships

Figure 4: Results in the Total sample: Innovation Level - New/improved products/services 


\subsubsection{Multi-group Analysis}

Table 6 presents the descriptive statistics (i.e. means, standard deviations and correlations among the study variables) referring to the multi-group analyses. The correlation matrix reported indicates the correlations between the study variables related to both the Greek and the UK sample.

Table 6: Means, standard deviations and correlations between the study variables in the multi-

group analyses $(G R, N=81 ; U K, N=49)$

\begin{tabular}{|c|c|c|c|c|c|c|c|c|c|c|c|c|c|c|c|}
\hline & & \multicolumn{2}{|c|}{ GR } & \multicolumn{2}{|c|}{ UK } & \multirow[b]{2}{*}{1} & \multirow[b]{2}{*}{2} & \multirow[b]{2}{*}{3} & \multirow[b]{2}{*}{4} & \multirow[b]{2}{*}{5} & \multirow[b]{2}{*}{6} & \multirow[b]{2}{*}{7} & \multirow[b]{2}{*}{8} & \multirow[b]{2}{*}{9} & \multirow[b]{2}{*}{10} \\
\hline & & Mean & SD & Mean & SD & & & & & & & & & & \\
\hline 1 & $\begin{array}{l}\text { Reduced time to } \\
\text { respond to } \\
\text { customers/suppliers }\end{array}$ & 4.23 & .96 & 3.65 & 1.09 & - & $.538^{* *}$ & $.525^{* *}$ & .192 & $.310^{*}$ & $.361^{*}$ & $.484^{* *}$ & .011 & .101 & .046 \\
\hline 2 & $\begin{array}{l}\text { Improved staff } \\
\text { communication }\end{array}$ & 3.50 & 1.10 & 3.53 & 1.10 & $.309^{* *}$ & - & $.808^{* *}$ & -.049 & .037 & .076 & $.537^{* *}$ & .012 & -.094 & .159 \\
\hline 3 & $\begin{array}{l}\text { Enhanced } \\
\text { staff/patients } \\
\text { satisfaction }\end{array}$ & 4.06 & .93 & 3.57 & 1.08 & $.515^{* *}$ & $.521^{* *}$ & - & -.211 & -.128 & .041 & $.553^{* *}$ & .208 & -.080 & .173 \\
\hline 4 & Economic risk & 3.69 & 1.08 & 4.16 & .87 & .154 & .064 & $.269^{*}$ & - & $.812^{* *}$ & $.528^{* *}$ & -.039 & .019 & $.356^{*}$ & -.191 \\
\hline 5 & Cost of innovation & 3.85 & .97 & 4.33 & .77 & .008 & -.040 & .051 & $.717^{* *}$ & - & $.669^{* *}$ & -.029 & -.027 & $.356^{*}$ & -.246 \\
\hline 6 & Lack of finance & 3.73 & .99 & 4.33 & .87 & -.039 & .024 & .125 & $.607^{* *}$ & $.704^{* *}$ & - & .129 & -.246 & $.315^{*}$ & -.156 \\
\hline 7 & $\begin{array}{l}\text { Access to } \\
\text { information }\end{array}$ & 3.63 & .78 & 3.51 & .69 & $.318^{* *}$ & $.401^{* *}$ & $.508^{* *}$ & -.046 & -.211 & -.166 & - & .193 & .036 & $.419^{* *}$ \\
\hline 8 & $\begin{array}{l}\text { External/internal } \\
\text { collaboration }\end{array}$ & 3.49 & .90 & 3.73 & .64 & $.347^{* *}$ & $.417^{* *}$ & $.389^{* *}$ & .106 & .055 & -.041 & $.340^{* *}$ & - & .141 & .153 \\
\hline 9 & $\begin{array}{l}\text { Innovation Level- } \\
\text { Technology }\end{array}$ & 4.07 & .89 & 3.92 & .78 & $.352^{* *}$ & .217 & $.283^{*}$ & -.101 & -.191 & $-.235^{*}$ & $.319^{* *}$ & $.380^{* *}$ & - & .199 \\
\hline 10 & $\begin{array}{l}\text { Innovation Level- } \\
\text { New/improved } \\
\text { products/services }\end{array}$ & 3.47 & .95 & 3.58 & .58 & $.232^{*}$ & $.316^{* *}$ & $.244^{*}$ & $-.227^{*}$ & -.146 & -.122 & $.273^{*}$ & $.310^{* *}$ & $.531^{* *}$ & - \\
\hline
\end{tabular}




\section{Results from the Greek and UK sample: Innovation Level - Technology and New/improved}

\section{products/services}

Results as shown in Table 7 state that, both in the Greek and UK samples, reduced time to respond to customers/suppliers, improved staff communication, enhanced staff/patient satisfaction, cost of innovation and lack of finance appeared to have no significant relationship with the innovation level regarding the use of technology and the introduction of new/improved products/services. According to Table 7, the relationship between external/internal collaboration and the innovation level regarding the use of technology might influence the Greek pharmacists' decision to innovate, while this was not the case regarding the UK sample. There is an indication suggesting that aspects of economic risk might act as a barrier to the introduction of new/improved products/services in the Greek delivery system, while this was absent in the UK group. Moreover, accessing information was considered an important element that might encourage UK pharmacists to introduce new/improved products/services, but this was not the case in the Greek sample. Finally, external/internal collaboration appeared to have no impact on decisions related to the introduction of new/improved products/services in both European contexts.

Table 7: Results of multi-group analysis: Innovation Level - Technology and New/improved

$$
\text { products/services }(G R, N=81 ; U K, N=49)
$$

\begin{tabular}{|l|c|c|c|c|c|c|c|c|}
\hline \multirow{2}{*}{ Variables } & \multicolumn{3}{|c|}{ Innovation Level - Technology } & \multicolumn{4}{c|}{$\begin{array}{c}\text { Innovation Level - } \\
\text { New/improved } \\
\text { products/services }\end{array}$} \\
\cline { 2 - 10 } & \multicolumn{2}{|c|}{ GR } & \multicolumn{2}{c|}{ UK } & \multicolumn{2}{c|}{ GR } & \multicolumn{2}{|c|}{ UK } \\
\cline { 2 - 9 } & $\boldsymbol{\beta}$ & $\boldsymbol{p}$ & $\boldsymbol{\beta}$ & $\boldsymbol{p}$ & $\boldsymbol{\beta}$ & $\boldsymbol{p}$ & $\boldsymbol{\beta}$ & $\boldsymbol{p}$ \\
\hline Reduced time to respond to & .239 & .058 & .017 & .932 & .102 & .426 & -.068 & .723 \\
customers/suppliers & & & & & & & & \\
Improved staff communication & -.084 & .516 & -.138 & .622 & .128 & .334 & .079 & .771 \\
Enhanced staff/patient satisfaction & .100 & .508 & -.009 & .977 & .099 & .526 & -.166 & .567 \\
Economic risk & -.066 & .675 & .156 & .536 & -.381 & $\mathbf{. 0 2 2}$ & -.010 & .967 \\
Cost of innovation & -.150 & .400 & .089 & .764 & .123 & .503 & -.204 & .481 \\
Lack of finance & -.023 & .886 & .217 & .333 & .049 & .768 & -.032 & .883 \\
Access to information & .112 & .385 & .051 & .784 & .125 & .347 & $\mathbf{. 4 8 3}$ & $\mathbf{. 0 1 1}$ \\
External/internal collaboration & $\mathbf{. 2 7 6}$ & $\mathbf{. 0 2 5}$ & .188 & .283 & .194 & .122 & .082 & .627 \\
\hline
\end{tabular}


Results in the Greek and UK sample: Innovation Level - New/improved products/services

Overall, economic risk seems to play an important role in the Greek pharmacists' decision to introduce innovative products and services. Apparently, the current economic crisis seems to have affected the pharmacists' decision to innovate. This unpleasant situation may have made them more sceptical and cautious about undertaking such initiatives. However, developing external/internal collaboration has a positive effect on the use of technology in the Greek context. Besides, the accessibility to relevant information might influence the UK pharmacies' decision to introduce new or improved products and services. Hospital and community pharmacists in the UK tend to believe that access to required data, knowledge and information can guide them to successfully introduce new or significantly improved services and products.

\section{Discussion}

To provide clarity to the discussion this section has been arranged around two core areas: i) Factors influencing the level of innovation within the downstream domain of the Pharmaceutical Supply Chain; and ii) Proposed Innovative programmes, which should be implemented to improvement of the downstream delivery of medicines.

\subsection{Factors influencing the level of innovation within the downstream domain of the} Pharmaceutical Supply Chain

From the data analysis, a better understanding of the level of innovation, regarding the use of technology and the introduction of new or improved products and services, applied in the UK and Greece, was achieved. Although Rowley et al. (2011), focusing on innovative interventions categorised these into two diverse types of innovation: i) technical innovation (e.g. Lai et al., 2008) 
and ii) product/service innovation (e.g. Lewis et al., 2010), Camison and Lopez (2010) argued that a clear distinction between them is not always possible.

Within this study, pharmacists operating in both geographical contexts recognised that the time to respond to customers and suppliers can be reduced by the use of technology (H1ai), this is something that is highly dependent on the knowledge and information sharing between the key stakeholders, as Kimpel (2013) and Pohjosenperä et al., (2018) explained. Blackstone (2010) purported that the use of technology and especially information systems (IS) enhances supply chains' performance through creating net value, synchronising supply with demand and leveraging worldwide logistics. Particularly, as Forslund and Jonsson (2007) and Chowdhury and Quaddus (2016) indicated, an effective and efficient delivery process requires access to accurate information regarding product usage and inventory levels. However, Magal and Word (2011) explained that these data are often fragmented by functional silos. They analysed it further, saying that a number of functions within organisations are often less communicative and collaborative, which does not support information sharing. Considering the high complexity of the PSC system, sharing information and knowledge is considered a very challenging process for healthcare organisations (Danese, 2006; Narayanamurthy et al., 2018). Indeed, although our participants revealed that they are quite satisfied with the software that they utilise to manage pharmaceuticals, they also stated that this is not an integrated system. The stakeholders involved within this process do not share the same IS, and so its capabilities are limited and focused only on internal practices. This can explain why pharmacists in both countries do not believe that the use of technology can improve their performance through enhancing the communication between them (H1bi) and their customers' satisfaction (H1ci).

Hypothesis 1 (H1), which assumed that reduced time to respond to customers/suppliers (a), improved staff communication (b) and enhanced staff/patients' satisfaction (c) positively influenced the innovation level regarding the introduction of new/improved products/services (ii), was rejected. Rostamy-Malkhalifeh and Mollaeian (2012) supported that the main reason for introducing new or relatively improved products and services is related to customer and staff satisfaction. However, 
Simon et al. (2007) and Narayanamurthy et al., (2018) found that healthcare organisations with strong hierarchical organisational systems have difficulties supporting new or significantly improved processes due to the current inefficiency of the system. Grol and Wensing (2004) supported this, explaining that disconnection between evidence and practice observed within the PSC has caused a slow uptake of innovation. The role of the physician as the main decision-maker (Bhakoo et al., 2012) in conjunction with autonomy issues and general healthcare organisations' cultural barriers (Levenson et al., 2008) appear to prevent the introduction of new or improved products and services. Healthcare personnel appear to be sensitised to changes, which means that they are more likely to perceive them as threat and react negatively (Burnes and Jackson, 2011).

From the data analysis, it is apparent that pharmacists tend to not consider the economic aspects of innovation, partly because they are not fully involved in the decision-making process related to the adoption of innovation and also due to the lack of knowledge and information related to the cost of innovative initiatives (H2). Bubalo et al. (2013) and Archibugi et al. (2013) reported that the cost of innovation and the lack of financial funds prevent innovation. In particular, Bubalo et al. (2013) investigated the aspects of technology and its effect on medication errors. Although they found that the application of Computerised Provider Order Entry (CPOE), Electronic Medical Record (EMR) and other similar software for placing pharmaceutical orders electronically has multiple benefits, the cost of implementing those types of technology were one of the limitations (Shafique $e t$ al., 2019). In addition, Davenport (2013) and Franco (2018), who also focused on the financial aspects of innovation, suggested that organisations often hesitate to undertake an innovative approach, fearing the economic risk associated with this type of initiative specifically when attempts to be innovative fail. Considering that the cost of pharmaceuticals is too high (Cherrett et al., 2012), pharmacies do not consider that purchasing and maintaining this type of technology requires huge investments. Wietholter et al. (2009) found that the cost of introducing, implementing and maintaining IS is dependent on the organisation's size. Therefore, attempts to implement this type of technology in a hospital environment could be very costly. However, the data analysis indicated that hospital 
pharmacists still do not consider this particular cost as a barrier to being innovative. On the contrary, more emphasis has been placed on selecting and adopting the appropriate innovative approach to fit with the organisation's needs, which is revealed by the output related to hypothesis 3 .

The data analysis of the total sample appears to confirm the positive effect of external and internal collaboration on innovation level regarding the use of technology (H3bi) and reject this positive relationship between access to information and the innovation level regarding the use of technology (H3ai). However, the total sample confirmed the positive relationship between access to information and external/internal collaboration and the innovation level regarding the introduction of new/improved products/services (H3aii and H3bii). Drucker (2014) and Papalexi et al. (2020) suggested that the development of synergies and information sharing between stakeholders of a supply chain enables organisations to successfully adopt innovative ideas and as a result increase their performance.

The participants in the Greek sample supported the assumed positive relationship between the development of internal and external collaboration and the use of technology (H3bi); however, the UK sample does not appear to believe that the development of collaborations enhances the use of technology. This can be explained based on the existence of technology asymmetries observed within the PSC (Archibugi et al., 2013; Narayanamurthy et al., 2018). Stakeholders involved within the PSC appear to operate quite independently using technology, and in particular information systems (IS), that fit within their organisational environment (Kim et al., 2012; Chowdhury and Quaddus, 2016). On the other hand, UK pharmacists emphasised more the importance of access to information in introducing new or significantly improved products and services (H3aii), which is not supported by the pharmacists operating in Greece.

Finally, regarding the assumed positive relationship between the access to information and the use of technology (H3ai), the data analysis indicated that pharmacies operating in both contexts do not support it. Elements such as the centralised environment (Narayanamurthy et al., 2018), the limited involvement of pharmacists in the decision-making process (Kastanioti et al., 2013; Altug 
and Sahin, 2019) and the organisational culture (Black et al., 2011; Dobrzykowski, 2019), have been considered as barriers to implementing innovation.

\subsection{Proposed Innovative programmes to improve the downstream delivery of medicines}

The research findings analysed the Greek and UK healthcare organisations' environment in order for the innovative programmes fitting within these contexts to be identified. Bamford et al. (2015) suggested that the adoption of innovation tends to be dependent on organisational context and characteristics, such as: the type of waste; needs and demands of stakeholders and functional rules regarding legal context. The adoption of Lean and Reverse Logistics (RL) approaches could help pharmacies to provide greater value to customers through more effective management and use of their resources and capabilities, which would create competitive advantage (Martín-Peña and DíazGarrido, 2008; Ferlie et al., 2016). From the research, Lean and RL are still considered as moderate innovations, (e.g. Arrighetti et al., 2014) as their implementation does not require specific equipment. However, constant small investments are needed to familiarise the stakeholders with the particular tools and techniques (Papalexi et al., 2015). By adopting those innovative approaches, therefore, stakeholders do not perceive the change as a threat, as it is achieved through applying a series of small adjustments (e.g. Burnes and Jackson, 2011; Papalexi, 2017).

Particularly, RL practices could facilitate the management of reverse components of the medicine delivery process, which would lead to a significant reduction in the level of wastage, preventing a negative impact on the society (Xie and Breen, 2014). Tran et al. (2014) stated that these products are produced in diverse forms and as a result their cost and expiration dates vary. By implementing Reverse Supply Chain Management (RSCM) within the PSC, a minimisation of product waste and the associated cost could be achieved, which leads to a reduction in storage space and reduction of funds tied up in assets (Papalexi et al., 2015; Chen et al., 2019). As a result, healthcare organisations would be able to meet the request of reducing spending on pharmaceuticals 
and increasing the quality of healthcare services by applying return policies. The data collected from this action could actively inform the supply and replenishment of medicines (Breen and Xie, 2015).

Unfortunately, the current delivery system applied in both selected contexts does not support such interventions. In particular, weak communication and limited knowledge and data exchange between the PSC stakeholders act as barriers to applying RL. It is suggested that the adoption of Lean approaches can overcome those obstacles, as these develop a continuous improvement roadmap, which requires the contribution of all actors of the supply chain (e.g. Hayes et al., 2014; Govindan $e t$ al., 2015; Papalexi et al., 2020; Altug and Sahin, 2019). Interestingly, Timmons et al. (2014), who examined aspects of Lean within a healthcare environment, found that the level of engagement and enthusiasm was significantly higher, which indicates the acceptability of such interventions. In addition, Hayes et al. (2014) suggested that patients' satisfaction and trust regarding the occupational expertise can be increased within a Lean environment. The use of the Lean tools and techniques, such as Just-In-Time (JIT) approaches, promote standardised processes and facilitate the collection and sharing of relevant data (e.g. Gong et al., 2014; Shafique et al., 2019). Lean and RL approaches also need to be supported by Benchmarking and the application of it can be beneficial for healthcare organisations aiming to improve their performance, as Benchmarking provides information on how best innovative approaches can be implemented and results realised (Adebanjo et al., 2010). The data analysis revealed a partial use of IT systems by pharmacies in both geographical areas; the need for compatible and integrated IT systems is apparent in order for the PSC stakeholders to be able to capture, store and manipulate the large volumes of data related to the use of pharmaceutical products (Feldman et al., 2012; Raghupathi and Raghupathi, 2014).

Figure 5 presents the developed Innovative Pharmaceutical Supply Chain Framework (IPSCF). Particularly, the IPSCF suggests the adoption, development and implementation of Lean and Reverse Logistics (RL) practices, which are supported by integrated Information Technology (IT) systems, to optimise the medicines delivery process and improve the PSC's effectiveness and efficiency. The framework has the potential to act as guidance to pharmacies and healthcare 
organisations, directing them to develop supply chains strategies according to which medicines waste reduction and the enhancement of service quality can be achieved.

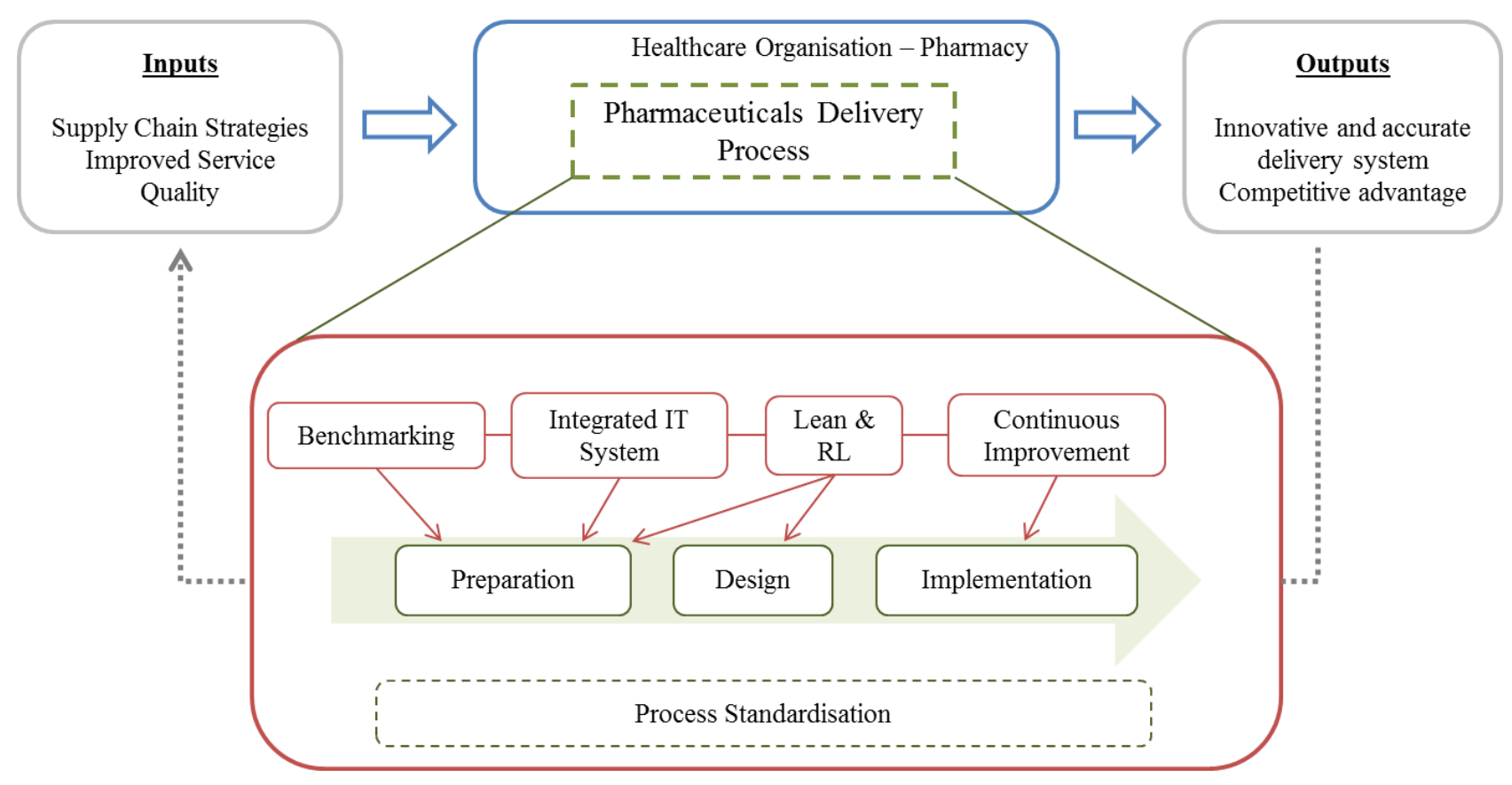

Figure 5: The Innovative Pharmaceutical Supply Chain Framework

Benchmarking can be used to collect relevant data and inform best practice and an integrated IT system utilised to speed up the delivery process. Perhaps more directly, and informed by this research, Lean and RL practices can be implemented to prepare and design an innovative, robust and accurate pharmaceutical delivery system, which leads toward continuous improvements (e.g. Arrighetti et al., 2014; Shafique et al., 2019). It supports the concept that by adopting best practices that have been successfully applied in a manufacturing setting, the delivery system can be enhanced in terms of quality (product and service quality), visibility (knowledge and information sharing), speed (response to customers' and suppliers' needs) and cost (minimisation of cost and waste). The IPSCF is tailored to the specific delivery practices undertaken within the downstream domain of the PSC in the two selected European contexts: the UK and Greece. However, it is believed that it can be adapted by the rest of the European countries as it has been apparent that the two study contexts operate similarly. 
In addition, the benefits generated can be greater if the suggested framework is implemented throughout the PSC as a whole.

\section{Conclusions}

Although, studies exist which explore PSC management, those that adopt a focused approach on downstream PSC activity as a cross-case comparative analysis are limited. This study reviewed and extended knowledge in this area and thus offers an incremental and revelatory contribution (Nicholson et al., 2018). The main areas where this research has potential implications for supply chain theory and practice are the following:

i) it adds a new dimension to the academic literature by investigating the subject of SCM, considering both hospitals and community pharmacies operating in the UK and Greece; it extends earlier work conducted by Bhakoo et al. (2012) on inventory management; Xie and Breen (2014) and Breen and Xie (2015) on waste management; and Burnes and Jackson (2011) on change management in healthcare. Furthermore, the focus of the study on country comparison answers the call for research suggested by Bravo and Carvalho (2015), who looked at optimisation of supply chains through return policies;

ii) it contributes to the academic literature by exploring the downstream domain of the PSC that was been far more scarcely discussed than the upstream (e.g., Danese, 2006; Narayana et al., 2014);

iii) it identifies the factors that could influence innovation adoption within the healthcare organisations, which matches Westrick and Mount's (2009) recommendations for further research, arguing that a combination of improvement approaches, such as Lean, with computerised methods could be the basis for enhanced innovation uptake;

iv) it addresses a critical issue for academics and practitioners, which is related to the challenge of how healthcare organisations could be more productive, whilst using fewer resources (e.g. Mustaffa and Potter, 2009; Xie and Breen, 2012; Al-Balushi et al., 2014; Papalexi et al., 2019). This was 
achieved by developing the Innovative Pharmaceutical Supply Chain Framework (IPSCF) (Figure 5), which suggests the implementation of Lean and Reverse Logistics (RL) practices for optimising the downstream domain of the PSC, using the available resources and capabilities. The IPSCF offers a new contribution to practice through providing a suggested solution of how best healthcare organisations could adopt innovation to improve the medicine delivery systems without increasing their expenses. This conceptual model visualises the medicine delivery process, when Lean and RL are implemented. It uses the benefits provided from them which improve the transportation process, and presents the outputs that the organisations could claim. Although the recommended improvements are based on theoretical evidence, it is believed that they could overcome the identified issues and they would not disrupt current practices. Furthermore, those improvements could support healthcare organisations to meet their goal of becoming world class institutes by promoting a teamwork environment, enhancing their operational efficiency, setting up processes for continuous improvement and eventually gaining an advantage over their perceived competitors.

The Covid-19 pandemic is a timely reminder that healthcare providers need to have well designed and effective systems to be resilient, responsive and innovative when faced with threats. Lack of access to critical equipment and medicines can be exacerbated by poor processes and systems that are not streamlined or transparent (Foster \& Neville, 2020). Pharmacy staff can be provided with the necessary training to develop their skills in lean techniques to improve their processes and systems, identifying failure points and deficiencies, which can contribute to delays in dispensing, medication errors and patient dissatisfaction. The return of medicines from patients and safe disposal of medications takes place in both hospital and community pharmacy settings (in hospital from wards - and in community pharmacy from patients or their representative). As the cost attributed to waste medicines is high, staff can proactively address this through greater transparency of stock allocation/rotation and storage facilities to identify problematic stockpiling, obsolescence or incorrect practice e.g. leaving stock unrefrigerated rendering it non-viable. Community pharmacy staff can also promote advocacy by educating and encouraging patients to return unwanted medicines for safe 
disposal. The race for the Covid-19 vaccine is now a priority for government bodies globally and the focus will then move to the vaccine supply chain. Innovative thinking informed by key practices such as Lean and RL, is much needed and timely to help design strategies to ensure that logistics into and within hospital/community pharmacies can support the robust supply chain needed for vaccine distribution (United Nations Environment Programme, 2020) and secure access to medicines in light of ongoing shortages (Hill, 2020).

The introduction of a RL system to encourage the return and recovery of medicines for further use or safe disposal and equipment e.g. medical devices, for refurbishment/repair, can save hospitals money but also make products more accessible for patients (e.g. returned to pharmacy stock from wards). Such innovation in the PSC is, from an economic, social and environmental perspective, an example of good practice. In a world with finite resources it is perhaps logical that staff should be encouraged to be innovative and work together to design such systems, and to ensure that stock is well managed using both manual and inventory management systems. The identification of Reverse Logistics and Lean Champions to lead staff to implement new and adapted systems could facilitate engagement and sustainability.

It should be noted that this paper, despite its theoretical and empirical merits, does have some limitations. One of the major challenges the authors faced conducting the current study was related to accessing data. Considering that professionals working within the PSC have a relatively heavy workload, a number of the potential participants were reluctant to be involved in this research. In addition to this, the study focuses only on the downstream domain of the PSC, which excludes those specialists operating within the upstream and central PSC domain. Moreover, some individuals were also excluded due to their limited knowledge of Operations Management (OM) and Supply Chain Management (SCM) practices. The authors acknowledge that the quantitative research findings, because of the limited total sample and the differences between the Greek and the UK settings and sample sizes, might not be easily generalisable or transferable to a broader context. It is recognised that the two-country sample used jointly may not be per se representative of a single population or a 
whole sector. However, because of the systematic nature of the work that took place involving among others comparisons with similarly positioned studies from the relevant literature and combination with a qualitative analysis, the findings provide accurate indications of the innovation opportunities reflecting and affecting the downstream PSC. In addition to this, the lack of financial data available had an impact on the research's contribution to practice. Considering that the main emphasis of healthcare organisations has been placed on reducing their drug spending, it is believed that the collection of financial data would have added value to the current thesis.

This paper has stated potential implications for supply chain theory and practice, and while the research itself provides insights into the factors that might affect the pharmacies' innovativeness, concentrating on the whole PSC could add more information, based on which a more reliable research could be achieved. The theoretical perspective of this study generates also another avenue of future research, which would be to target and examine the performance of PSCs where innovative approaches, such as Lean and RL practices, have been considered and implemented. As the current study has been focused on the delivery practices applied within two European contexts, researchers are encouraged to investigate the aspects of the PSC adopted across European boundaries.

\section{References}

Adebanjo, D., Abbas, A. and Mann R. (2010). "An investigation of the adoption and implementation of benchmarking". International Journal of Operations \& Production Management, Vol.30 No.11, pp.1140-1169.

Al-Balushi, S., Sohal, A.S., Singh, P.J., Al Hajri, A., Al Farsi, Y.M. and Al Abri, R. (2014), "Readiness factors for lean implementation in healthcare settings - a literature review", Journal of Health Organization and Management, Vol.28 No.2, pp.135-153.

Altug, M.S. and Sahin, O. (2019). "Impact of Parallel Imports on Pricing and Product Launch Decisions in Pharmaceutical Industry". Production and Operations Management, Vol.28 No.2, pp.258-275. 
Archibugi, D., Filippetti, A. and Frenz, M. (2013). "Economic crisis and innovation: Is destruction prevailing over accumulation?" Research Policy. Vol.42 No2, pp.303-314

Arrighetti, A., Landini, F. and Lasagni, A. (2014). "Intangible assets and firm heterogeneity: Evidence from Italy". Research Policy, Vol.43 No.1, pp.202-213.

Baird, B. and Beech, J. (2020). "Community pharmacy explained" The King's fund. Available at: https://www.kingsfund.org.uk/publications/community-pharmacy-explained

Baker, G. (2014). "Improving Healthcare Using Lean Processes". Healthcare quality, Vol.17 No.2, pp.18-19

Bam, L., McLaren, Z. M., Coetzee, E. and von Leipzig, K. H. (2017). "Reducing stock-outs of essential tuberculosis medicines: a system dynamics modelling approach to supply chain management", Health Policy and Planning, Vol.32 No8, pp. 1127-1134.

Bamford, D., Forrester, P., Dehe, B. and Leese, R. (2015). "Partial and iterative Lean implementation: Two case studies". International Journal of Operations and Production Management. Vol.35 No.5, pp.702-727.

Battini, D., Faccio, M., Persona, A., and Sgarbossa, F. (2013). "Modelling the Growing Process of Integrated Healthcare Supply Networks". International Journal of System Dynamics Applications, Vol.2 No.1, pp.1-13.

Bhakoo, V., Singh, P., and Sohal, A. (2012). "Collaborative management of inventory in Australian hospital supply chains: practices and issues". Supply Chain Management: An International Journal, Vol.17, No.2, pp.217-230.

Birkie, S. E., Trucco, P. and Campos, P. F. (2017) "Effectiveness of resilience capabilities in mitigating disruptions: leveraging on supply chain structural complexity", Supply Chain Management: An International Journal, Vol. 22 No.6, pp.506-521.

Black, A., Car, J., Pagliari, C., Anandan, C., Cresswell, K. and Bokun, T. et al. (2011). "The Impact of eHealth on the Quality and Safety of Health Care: A Systematic Overview". Plos Med, Vol.8 No.1, e1000387. http://dx.doi.org/10.1371/journal.pmed.1000387

Blackhurst, J., Wu, T. and O'Grady, P. (2004). "Network-based approach to modelling uncertainty in a supply chain". International Journal of Production Research. Vol. 42, pp. 1639-1658.

Blackstone, J. H. (ed.) (2010). APICS Dictionary, 13th Edition. [Online]. Retrieved from: http://www.apics.org/industry-content-research/publications/apics-dictionary [Accessed 2013-0129].

Boulet, S., Boudot, E. and Houel, N. (2016). "Relationships between each part of the spinal curves and upright posture using Multiple stepwise linear regression analysis". Journal of Biomechanics. http://dx.doi.org/10.1016/j.jbiomech.2016.02.054

Braga, M., Tyler, M., Rhoads, J., Cacchio, M., Auerbach, M., Nishisaki, A. and Larson, R. (2015). "Effect of just-in-time simulation training on provider performance and patient outcomes for clinical procedures: a systematic review". BMJ Simulation And Technology Enhanced Learning, bmjstel-2015-000058.

Braun, V. and Clarke, V. (2013) Successful qualitative research: A practical guide for beginners. London: Sage.

Bravo, A. and Carvalho, J. (2015). "Challenging times to pharmaceutical supply chains towards sustainability: a case study application". International Journal of Procurement Management, Vol,8 No.1/2, pp.126. http://dx.doi.org/10.1504/ijpm.2015.066292

Breen, L. and Xie, Y. (2015). "Waste not, want not. What are the drivers of sustainable medicines recycling in National Health Service hospital pharmacies (UK)?". International Journal of Procurement Management, Vol.8, No.1/2, pp.82.

Bubalo, J., Warden, B., Wiegel, J., Nishida, T., Handel, E. and Svoboda, L. (2013). "Does applying technology throughout the medication use process improve patient safety with antineoplastics?" Journal Of Oncology Pharmacy Practice, Vol.20 No.6, pp.445-460.

Burgess, N. and Radnor, Z. (2013). "Evaluating Lean in healthcare". International Journal of Health Care Quality Assurance, Vol.26 No.3, pp.220-235. 
Burnes, B., and Jackson, P. (2011). "Success and failure in organizational change: An exploration of the role of values". Journal of Change Management, Vol.11 No2, pp.133-162.

Camison, C. and Lopez, A.V., (2010). "An examination of the relationship between manufacturing flexibility and firm performance". International Journal of Operations \& Production Management. Vol.30, pp.853-878.

Campos, E., Paula, I., Pagani, R. and Guarnieri, P., (2017). Reverse logistics for the end-of-life and end-of-use products in the pharmaceutical industry: a systematic literature review. Supply Chain Management: An International Journal, 22(4), pp.375-392.

Cha, E. S., Kim, K. H. and Erlen, J. A. (2007). "Translation of scales in cross-cultural research: Issues and techniques", Journal of Advanced Nursing, Vol.58 No.4, pp.386-395.

Chen, X., Yang, H. and Wang, X. (2019). "Effects of price cap regulation on the pharmaceutical supply chain". Journal of Business Research, Vol.97, pp.281-290. doi:10.1016/j.jbusres.2018.01.030

Cheng, J. L. C., Henisz, W. J., Roth, K., and Swaminathan, A. (2009). "From the Editors: advancing interdisciplinary research in the field of international business: prospects, issues and challenges". Journal of International Business Studies, Vol.40 No7, pp.1070-1074.

Cherrett, T.J., Maynard, S., McLeod, F.N. and Hickford, A.J. (2012) "Reverse logistics for the management of waste". in McKinnon, A., et al. (Eds), Green Logistics: Improving the environmental sustainability of logistics, London, GB, Kogan, pp. 242-262.

Chowdhury, M.d. Hossan, M. and Quaddus, M. (2016). "Supply Chain Readiness, Response and Recovery For Resilience". Supply Chain Management: An International Journal Vol.21, No.6, pp. 709-731.

Cranfield, S., Hendy, J., Reeves, B., Hutchings, A., Collin, S. and Fulop, N. (2015). "Investigating healthcare IT innovations: a 'conceptual blending' approach". Journal of Health Organization And Management, Vol.29 No.7, pp.1131-1148.

Creswell J.W. and Plano Clark V.L. (2011). Designing and Conducting Mixed Methods Research. SAGE, Thousand Oaks, CA.

Danas, K., Rondsari, A. and Ketikidis, P.H. (2006). "The applicability of a multi-attribute classification framework in the health care industry". Journal of Manufacturing Technology Management. Vol.17 No.6, pp.772-85.

Danese, P. (2006). "The extended VMI for coordinating the whole supply network". Journal of Manufacturing Technology Management, Vol.17 No.7, pp.888-907.

Davenport, T.H. (2013). Process innovation: reengineering work through information technology. Harvard Business School Press.

Davies B. and Edwards N. (2013) "Sustaining knowledge use. In Knowledge Translation in Health Care: Moving from Evidence to Practice" (Straus S. E., Tetroe J. \& Graham I.D., eds), WileyBlackwell, West Sussex, UK, pp. 165-173.

Dawes, J. G. (2008). "Do data characteristics change according to the number of scale points used? An experiment using 5 point, 7 point and 10 point scales". International journal of market research, Vol.51 No.1.

De Vries, J. and Huijsman, R., (2011). "Supply chain management in health services: an overview". Supply Chain Management: An International Journal. Vol.16, No.3, pp.159-165.

Defee, C.C., Esper, T. and Mollenkopf, D. (2009). "Leveraging closed-loop orientation and leadership for environmental sustainability". Supply Chain Management: An International Journal, Vol.14, No.2., pp. 87-98.

Department of Health and Social Care (DHSC) (2019), DHSC single departmental plan, available at:https://www.gov.uk/government/publications/department-of-health-single-departmentalplan/dhsc-single-departmental-plan\#support-research-and-innovation-to-maximise-health-andeconomic-productivity 
Dobrzykowski, D. (2019). "Understanding the downstream healthcare supply chain: unpacking regulatory and industry characteristics". Journal of Supply Chain management, Vol.55 No.2, pp. 26-46.

Drucker, P. (2014). Innovation and entrepreneurship. New York: Routledge.

Edwards, Z. Blenkinsopp. A, Ziegler. L. and Bennett. M.I. (2018). "How do patients with cancer pain view community pharmacy services? An Interview study". Health \& Social Care in the Community. 00:1-12 DOI:10.1111/hsc12549

Esfahbodi, A., Zhang, Y. and Watson, G. (2016). "Sustainable supply chain management in emerging economies: Trade-offs between environmental and cost performance". International Journal of Production Economics. doi:10.1016/j.ijpe.2016.02.013.

European Medicines Agency. (2014). "The European regulatory system for medicines and the European Medicines Agency: A consistent approach to medicines regulation across the European Union". Science Medicines Health. available at: http://www.ema.europa.eu/docs/en_GB/document_library/Brochure/2014/08/WC500171674.pdf Eurostat, (2018), "Healthcare personnel statistics - dentists, pharmacists and physiotherapists" Available https://ec.europa.eu/eurostat/statisticsexplained/index.php/Healthcare_personnel_statistics_denti sts, pharmacists_and_physiotherapists

Fawcett, S.E. and Magnan, G.M. (2002), "The rhetoric and reality of supply chain integration", International Journal of Physical Distribution \& Logistics Management, 32 (5), 339-61.

Feldman, B., Martin, E.M. and Skotnes, T. (2012). "Big Data in Healthcare Hype and Hope". Dr. Bonnie 360, Available at: http://www.west-info.eu/files/big-data-inhealthcare.pdf.

Feldon, D. F. and Kafai. Y. B. (2008). "Mixed methods for mixed reality: understanding users' avatar activities in virtual worlds". Educational Technology Research and Development, Vol.56, pp.575-593.

Ferlie, E., Crilly, T., Jashapara, A., Trenholm, S., Peckham A. and Currie, G. (2016). "Strategic Management in the Healthcare Sector: The Debate About the Resource-Based View Flourishes in Response to Recent Commentaries". International Journal of Health Policy Management, Vol.5 No.2, pp.145-14.

Forslund, H. and Jonsson, P. (2007). "The impact of forecast information quality on supply chain performance". International Journal of Operations \& Production Management, Vol.27, pp.90-107 Franco, C. (2018). "A simulation model to evaluate pharmaceutical supply chain costs in hospitals: The case of a colombian hospital. DARU", Journal of Pharmaceutical Sciences, doi:10.1007/s40199-018-0218-0

Freeman, T., Dickinson, H., McIver, S. and McLeod, H., (2006). "Innovation in service delivery: a literature review on the characteristics of innovation and improvement". Health Services Management Centre, University of Birmingham.

Galloway, L. (2021). "Hospital Pharmacy", Royal Pharmaceutical Society. Available at: https://www.rpharms.com/resources/careers-information/career-options-in-pharmacy/hospital-

pharmacy

General Pharmaceutical Council (GPhC) (2011). "Future pharmacists Standards for the initial education and training of pharmacists". Available at: https://www.pharmacyregulation.org/sites/default/files/document/gphc_future_pharmacists_may 2011.pdf

Gölgeci, I. and Ponomarov, S.Y. (2015), "How does firm innovativeness enable supply chain resilience? The moderating role of supply uncertainty and interdependence", Technology Analysis \& Strategic Management, Vol. 27 No. 3, pp. 267-282.

Gong, Q, Yang, Y. and Wang, S. (2014). "Information and decision-making delays in MRP, KANBAN, and CONWIP”, International Journal of Production Economics, Vol.156, pp.208-213. 
Golicic, S. L., \& Davis, D. F. (2012). Implementing mixed methods research in supply chain management. International Journal of Physical Distribution \& Logistics Management, 42 (8/9), 726-741.

Govindan, K., Azevedo, S.G. and Carvalho, H. (2015). "Lean, green and resilient practices influence on supply chain performance: interpretive structural modelling approach". International Journal of Environment Science and Technology. Vol.12, pp.15-34.

Gravetter, F. and Wallnau, L. (2011). Essentials of Statistics for the Behavioral Sciences. USA, Belmont: Cengage Learning.

Greenhalgh. T., Macfarlane F., Barton-Sweeney C. and Woodard F. (2012) "If we build it, will it stay? A case study of the sustainability of whole-system change in London". Milbank Quarterly Vol.90 No3, pp.516-547.

Grol, R. and Wensing, M., (2004). "What drives change? Barriers and incentives for achieving evidence-based practice". Medical Journalists' Association. Vol.180, pp.7-60.

Groves, R. M., Fowler Jr, F. J., Couper, M. P., Lepkowski, J. M., Singer, E. and Tourangeau, R. (2011) Survey methodology. John Wiley \& Sons.

Guest, G., MacQueen, K. M. and Namey, E. E. (2012) Applied thematic analysis. Thousand Oaks, CA: Sage.

Hill, A. (2020) "Ways to safeguard UK drug supplies during COVID-19 and beyond". The Pharmaceutical Journal. Available at: https://www.pharmaceutical-journal.com/news-andanalysis/opinion/comment/ways-to-safeguard-uk-drug-supplies-during-covid-19-and-

beyond/20207897.article?firstPass=false

Hodgkinson, G.P. and Rousseau, D.M. (2009). "Bridging the rigour-relevance gap in management research: it's already happening!", Journal of Management Studies, Vol.46 No.3, pp.534-546.

Kang Sherman Heng, H. and Loosemore, M. (2013). "Structural holes in hospital organisations. Engineering", Construction And Architectural Management, Vol.20 No.5, pp.474-487. http://dx.doi.org/10.1108/ecam-05-2011-0045

Kastanioti, C., Kontodimopoulos, N., Stasinopoulos, D., Kapetaneas, N. and Polyzos, N. (2013). "Public procurement of health technologies in Greece in an era of economic crisis". Health Policy, Vol.109 No.1, pp.7-13.

Kim, D., Kumar, V. and Kumar, U. (2012). "Relationship between quality management practices and innovation”. Journal Of Operations Management, Vol.30 No.4, pp.295-315.

Kimpel, J.F. (2013). "Critical success factors for data warehousing: A classing answer to a modern question". Issues in Information Systems. Vol.14 No.1, pp.376-384.

Kumar S., Dieveney E. and Dieveney A. (2009) "Reverse logistic process control measures for the pharmaceutical industry supply chain". International Journal of Productivity and Performance Management, Vol.58, No.2, pp.188-204.

Lai, F., Li, D., Wang, Q. and Zhao, X., (2008). "The information technology capability of thirdparty logistics providers: a resource-based view and empirical evidence from China". Journal of Supply Chain Management. Vol.44, pp.22-38.

Levenson, R., Dewar, S. and Shepherd, S. (2008). "Understanding Doctors, The Royal College of Physicians and the King's Fund", London, Available at: www.kingsfund.org.uk/document.rm?id=7617.

Lewis, M., Brandon-Jones, A., Slack, N. and Howard, M., (2010). "Competing through operations and supply: the role of classic and extended resource-based advantage". International Journal of Operations \& Production Management. Vol.30, pp.1032-1058.

Lima, F., Da Silva, A., Godinho Filho, M. and Dias, E., (2018). Systematic review: resilience enablers to combat counterfeit medicines. Supply Chain Management: An International Journal, 12(3), pp.117-135.

Lionis, C., Symvoulakis, E and Markaki, A., Vardavas, C., Papadakaki, M. Daniilidou, N. Souliotis, K. and Kyriopoulos, I. (2009) "Integrated primary health care in Greece, a missing issue 
in the current health policy agenda: a systematic review". International Journal of Integrated Care, Vol.9, pp.1568-4156.

Magal, S. and Word, J. (2011). Integrated Business Processes with ERP Systems. Hoboken NJ: Wiley

Maneesriwongul, W. and Dixon, J. K. (2004) "Instrument translation process: A methods review", Journal of Advanced Nursing, Vol.48 No.2, pp.175-186.

Manning, M., Purrington, K., Penner, L., Duric, N. and Albrecht, T. (2016). "Between-race differences in the effects of breast density information and information about new imaging technology on breast-health decision-making". Patient Education And Counseling. http://dx.doi.org/10.1016/j.pec.2016.01.010

Medical Waste Management Market. (2018). "Markets and Markets Research". Available at: https://www.marketsandmarkets.com/Market-Reports/medical-waste-management-market-

1256.html

Mikulic, M. (2019). "Global spending on medicines from 2010, 2018 and a forecast for 2023 (in billion U.S. dollars)". Statista. Available at: https://www.statista.com/statistics/280572/medicinespending-worldwide, accessed 01.11.2019

Mustaffa, N.H. and Potter, A., (2009). "Healthcare supply chain management in Malaysia: a case study”. Supply Chain Management: An International Journal. Vol.14 No.3, pp.234-243.

Narayana, S., Kumar Pati, R., and Vrat, P. (2014). "Managerial research on the pharmaceutical supply chain - A critical review and some insights for future directions". Journal Of Purchasing And Supply Management, Vol.20, No.1, pp.18-40.

Narayanamurthy, G., Gurumurthy, A., Subramanian, N. and Moser, R. (2018). "Assessing the readiness to implement lean in healthcare institutions - A case study". International Journal Of Production Economics, Vol.197, pp.123-142.

National Organisation for Medicines. (NOfM) (2016). "The Organisation's aim and objectives". Available at: https://www.eof.gr/web/guest/information

Nicholson, J., LaPlaca, P., Al-Abdin, A., Breese, R. and Khan, Z. (2018). "What do introduction sections tell us about the intent of scholarly work: A contribution on contributions". Industrial Marketing Management, Vol.73, pp.206-219.

Nikitas, A., Avineri, E. \& Parkhurst, G. (2018). "Understanding the public acceptability of road pricing and the roles of older age, social norms, pro-social values and trust for urban policy-making: The case of Bristol". Cities, Vol.79, pp.78-91.

Nikitas, A., Wang, J. Y. and Knamiller, C. (2019). "Exploring parental perceptions about school travel and walking school buses: A thematic analysis approach". Transportation Research Part A: Policy and Practice, Vol.124, pp.468-487.

O'Reilly, M. and Parker, N. (2012). "Unsatisfactory saturation: A critical exploration of the notion of saturated sample sizes in qualitative research". Qualitative Research Journal, pp.1-8.

OECD Health Data (2019), Health spending. Available at: https://data.oecd.org/healthres/healthspending.htm

Papalexi, M. (2017). An investigation into the aspects of innovation within the downstream domain of the pharmaceutical supply chain. PhD thesis. University of Huddersfield.

Papalexi, M., Bamford, D. and Breen, L. (2020), "Key sources of operational inefficiency in the pharmaceutical supply chain", Supply Chain Management, Vol. 25 No. 6, pp. 617-635. https://doi.org/10.1108/SCM-02-2019-0076

Papalexi, M., Bamford, D. and Dehe, B. (2015). "A case study of Kanban implementation within the Pharmaceutical Supply Chain." International Journal of Logistics Research and Applications. Vol. 19, No.4, pp.239-255.

Pohjosenperä, T., Kekkonen, P., Pekkarinen, S. and Juga, J. (2018). "Service modularity in managing healthcare logistics". The International Journal Of Logistics Management. Vol.30 No1, pp.174-194. 
Raghupathi, W. and Raghupathi, V. (2014). "Big data analytics in healthcare: promise and potential". Health Information Science and Systems, Vol.2 No.1, pp.3.

Radnor, Z. and Barnes, D. (2007). "Historical analysis of performance measurement and management in operations management". International Journal of Productivity and Performance Management, 56(5), pp. 384-396.

Rostamy-Malkhalifeh, M. and Mollaeian, E. (2012). "Evaluating performance supply chain by a new non-radial network DEA model with fuzzy data". Data Envelopment Analysis And Decision Science, pp.1-9.

Rowley, J., Baregheh, A. and Sambrook, S. (2011). "Towards an innovation-type mapping tool”. Management Decision, Vol.49 No.1, pp.73 - 86.

Schadewaldt, V., McInnes, E. Hiller, J.E. and Gardner, A. (2014). "Investigating characteristics of collaboration between nurse practitioners and medical practitioners in primary health care: a mixed methods multiple case study protocol". Journal of Advanced Nursing Vol.70 No.5, pp.1184-1193. Shafique, M. N., Khurshid, M. M., Rahman, H., Khanna, A. and Gupta, D. (2019). "The role of big data predictive analytics and radio frequency identification in the pharmaceutical industry". IEEE Access, Vol.7, pp.9013-9021. doi:10.1109/ACCESS.2018.2890551

Shah, N. (2004). "Pharmaceutical supply chains: key issues and strategies for optimisation". Computers \& Chemical Engineering. Vol.28 No.6/7, pp.929-41.

Simchi-Levi, D., Kaminsky, P. and Simchi-Levi, E. (2008). Designing and Managing the Supply Chain: Concepts, Strategies and Case Studies. McGraw-Hill, New York, NY.

Simon, J., Rundall, T. and Shortell, S. (2007). "Adoption of Order Entry with Decision Support for Chronic Care by Physician Organizations". Journal of The American Medical Informatics Association, Vol.14 No.4, pp.432-439.

Timmons, S., Coffey, F. and Vezyridis, P. (2014). "Implementing lean methods in the Emergency Department”. Journal Of Health Organization And Management, Vol.28 No.2, pp.214-228.

Tongco, M., (2007). "Purposive Sampling as a Tool for Informant Selection". Ethnobotany research and application, Vol.5 No2, pp. 147-158

Tran, N., Hu, J., Li, J. and Ong, S. (2014). "Suitability of artificial sweeteners as indicators of raw wastewater contamination in surface water and groundwater". Water Research, Vol.48, pp.443456.

United Nations Environment Programme (2020). Why optimized cold-chains could save a billion COVID vaccines. Accessed: 6 Sept. 2020. https://www.unenvironment.org/news-andstories/story/why-optimized-cold-chains-could-save-billion-covid-vaccines

Vaismoradi, M., Jones, J., Turunen, H., and Snelgrove, S. (2016). "Theme development in qualitative content analysis and thematic analysis". Journal of Nursing Education and Practice, Vol.6, No.5.

Wang, Z., Zhang, X., Huang, Y. and Wang, H. (2015). "Comprehensive evaluation of pharmaceuticals and personal care products (PPCPs) in typical highly urbanized regions across China”. Environmental Pollution, Vol.204, pp.223-232.

Weraikat, D., Zanjani, M. K. and Lehoux, N. (2019). "Improving sustainability in a two-level pharmaceutical supply chain through vendor-managed inventory system". Operations Research for Health Care, Vol.21, pp.44-55.

Westrick, S. and Mount, J. (2009). "Impact of perceived innovation characteristics on adoption of pharmacy-based in-house immunization services". International Journal of Pharmacy Practice, Vol.17, No.1, pp.39-46.

Wietholter, J., Sitterson, S. and Allison, S. (2009). "Effects of computerized prescriber order entry on pharmacy order-processing time". American Journal Of Health-System Pharmacy, Vol.66 No.15, pp.1394-1398.

Williams, I. (2011) Organizational readiness for innovation in health care: some lessons from the recent literature. Health Services Management Research. 1-6. 
Xie, Y. and Breen, L. (2012) "Greening community pharmaceutical supply chain in UK: a cross boundary approach”. Supply Chain Management: An International Journal. Vol.7 No1, pp.40-53. Xie, Y. and Breen, L. (2014). "Who cares wins? A comparative analysis of household waste medicines and batteries reverse logistics systems". Supply Chain Management: An International Journal. Vol.19 No4, pp.455-474.

\section{Appendices}

\section{Appendix 1: Survey instrument}

Deployment of innovation within the PSC

Page 1: Welcome

I would like to invite you to take part in the study named above. Your response will contribute to a $\mathrm{PhD}$ project on deployment of innovative programmes within the Pharmaceutical Supply Chain.

Purpose of the survey: The purpose of this survey is to collect information about innovative programmes within the Pharmaceutical Supply Chain in the UK. There has been pressure on the NHS, and generally on healthcare organisations, to keep a tight rein on their drugs spending. The annual drugs bill in the UK is approximately $£ 10$ billion, which equates to about $10 \%$ of NHS expenditure, having risen 3.5\% a year between 2007 and 2011 (McKee, 2012). Therefore, pharmacies tend to concentrate on innovative programmes to reduce waste and costs, while improving quality of services (Odier, 2010). Hence, the aim of the study is to explore the impact of innovation upon productivity and performance over the last five years.

Please respond to all questions (unless otherwise instructed) as this will allow comparisons to be made between respondents.

To encourage your participation in the survey a prize is being offered which is a 8.3" Tablet: Tesco hudl 2. The winner will be selected via a random computerised draw selection process which will be carried out the next working day after the relevant close date.

Definition of Innovation: Innovation, for the purpose of this survey, is defined as new or significantly improved products, services or processes used to produce or supply any products or services that the organisation delivers. The innovation (new or improved) must be new to the organisation, but it does not need to be new to the healthcare sector. Information Required: Section 1 - Innovation Activities; Section 2 - Context for Innovation; Section 3 - General Information.

I would be very interested to hear your experiences. Please help by filling in the relevant box; it should only take 10-15 minutes of your time. Your answers will be kept anonymous and strictly confidential. If you would like any further information or details of the study, please contact: Marina Papalexi via email: M.papalexi@hud.ac.uk

Thank you for your participation and support! 
Note that responses are not saved until you have clicked on the CONTINUE button at the bottom of each page. You cannot return to review or amend a previous page.

Mckee, S., (2012), 'NHS spend on new drugs set to shrink', PharmaTimes online magazine. Retrieved from

http://www.pharmatimes.com/article/12-07-03/NHS_spend_on_new_drugs_set_to_shrink.aspx

Odier, N., (2010), The US health-care system: A proposal for reform. Journal of Medical Marketing, $10,279-304$.

\section{Page 2: Section 1 - Innovation Activities}

The following questions are related to changes in organisation strategy and practices over the last five years; investments in current and future innovation and the introduction of new or improved products, services and processes.

This part of the survey uses a table of questions, view as separate questions instead?

1. To what extent the pharmacy has invested in any of the following, for the purposes of current or future innovation:

\begin{tabular}{|c|c|c|c|c|c|}
\hline & $\begin{array}{l}\text { Strongly } \\
\text { Disagree }\end{array}$ & Disagree & $\begin{array}{c}\text { No } \\
\text { Opinion }\end{array}$ & Agree & $\begin{array}{c}\text { Strongly } \\
\text { Agree }\end{array}$ \\
\hline $\begin{array}{l}\text { Acquisition of advanced machinery, equipment and } \\
\text { software for innovation: }\end{array}$ & $\mathrm{C}$ & $\mathrm{C}$ & $\mathrm{C}$ & $\mathrm{C}$ & $\mathrm{C}$ \\
\hline Computer hardware & $C$ & $\mathrm{C}$ & $\mathrm{C}$ & $\mathrm{C}$ & $\mathrm{C}$ \\
\hline Computer software & $\mathrm{C}$ & $\mathrm{C}$ & $\mathrm{C}$ & $\mathrm{C}$ & $\mathrm{C}$ \\
\hline
\end{tabular}

This part of the survey uses a table of questions, view as separate questions instead?

2. For each of the main innovation related investments in question 2, please ESTIMATE the amount of expenditure. Where precise figures cannot be provided please give your best estimates

$\mathfrak{f ( a n n u a l l y )}$

\begin{tabular}{|c|c|c|c|c|c|}
\hline $\begin{array}{c}0- \\
5.000\end{array}$ & $\begin{array}{l}5.000- \\
10.000\end{array}$ & $\begin{array}{c}10.000- \\
15.000\end{array}$ & $\begin{array}{c}15.000- \\
20.000\end{array}$ & $\begin{array}{c}\text { More than } \\
20.000\end{array}$ & $\begin{array}{c}\text { I do not } \\
\text { know }\end{array}$ \\
\hline
\end{tabular}


Acquisition of advanced machinery, equipment and software for innovation

Training for innovative activities

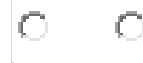

C C
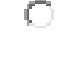

6

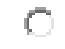

C

C

This part of the sl 14499754 urvey uses a table of questions, view as separate questions instead?

3. To what extent the pharmacy has introduced
New or significantly improved products

New or significantly improved services/processes for delivering products

This part of the survey uses a table of questions, view as separate questions instead?

4. Please ESTIMATE the percentage of the organisation's total turnover from products and services/process that were:

\begin{tabular}{|c|c|c|c|c|c|c|c|c|c|}
\hline & $\begin{array}{l}0 \%- \\
10 \%\end{array}$ & $\begin{array}{l}10 \%= \\
20 \%\end{array}$ & $\begin{array}{l}20 \%- \\
30 \%\end{array}$ & $\begin{array}{l}30 \%= \\
40 \%\end{array}$ & $\begin{array}{l}40 \%= \\
50 \%\end{array}$ & $\begin{array}{l}50 \%- \\
60 \%\end{array}$ & $\begin{array}{l}60 \%= \\
70 \%\end{array}$ & $\begin{array}{c}\text { More than } \\
70 \%\end{array}$ & $\begin{array}{c}\text { I do not } \\
\text { know }\end{array}$ \\
\hline New to your market & $C$ & $\mathrm{C}$ & $\mathrm{C}$ & $\mathrm{C}$ & $\mathrm{C}$ & $\mathrm{C}$ & $\mathrm{C}$ & $C$ & $\mathrm{C}$ \\
\hline $\begin{array}{l}\text { Significantly } \\
\text { improved }\end{array}$ & $C$ & $C$ & $C$ & $C$ & $C$ & $C$ & $C$ & $C$ & $C$ \\
\hline Total turnover & $C$ & $C$ & $C$ & $\mathrm{C}$ & $C$ & $C$ & $C$ & $C$ & $C$ \\
\hline
\end{tabular}

Page 3: Section 2 - Context for Innovation 
This part of the survey uses a table of questions, view as separate questions instead?

5. To what extent the following factors were important in your decision to innovate in products, services or processes

\begin{tabular}{|c|c|c|c|c|c|}
\hline & $\begin{array}{c}\text { Not Important at } \\
\text { All }\end{array}$ & $\begin{array}{l}\text { Somewhat } \\
\text { Important }\end{array}$ & Net & Important & $\begin{array}{c}\text { Very } \\
\text { Important }\end{array}$ \\
\hline $\begin{array}{l}\text { Improved flexibility of production or } \\
\text { service provision }\end{array}$ & C & $\mathrm{C}$ & $\mathrm{C}$ & $\mathrm{C}$ & $\mathrm{C}$ \\
\hline $\begin{array}{l}\text { Reduced time to respond to customer or } \\
\text { supplier needs }\end{array}$ & C & C & $\mathrm{C}$ & $\mathrm{C}$ & $\mathrm{C}$ \\
\hline Improved staff communication & C & $\mathrm{C}$ & $\mathrm{C}$ & $\mathrm{C}$ & $\mathrm{C}$ \\
\hline Enhanced staff or patient satisfaction & C & $\mathrm{C}$ & $\mathrm{C}$ & $\mathrm{C}$ & $\mathrm{C}$ \\
\hline
\end{tabular}

This part of the survey uses a table of questions, view as separate questions instead?

6. To what extent information from each of the following sources was important to your organisation's innovation activities

\begin{tabular}{|c|c|c|c|c|c|}
\hline & $\begin{array}{c}\text { Not Important at } \\
\text { All }\end{array}$ & $\begin{array}{l}\text { Somewhat } \\
\text { Important }\end{array}$ & Net & Important & $\begin{array}{c}\text { Very } \\
\text { Important }\end{array}$ \\
\hline Your organisation & C & $\mathrm{C}$ & $\mathrm{C}$ & $\mathrm{C}$ & $\mathrm{C}$ \\
\hline $\begin{array}{l}\text { Suppliers of equipment, materials, services } \\
\text { or software }\end{array}$ & $\mathrm{C}$ & C & $\mathrm{C}$ & $\mathrm{C}$ & $\mathrm{C}$ \\
\hline Patients or end users & $\mathrm{C}$ & $\mathrm{C}$ & $\mathrm{C}$ & $\mathrm{C}$ & $\mathrm{C}$ \\
\hline Government or public research institutes & $\mathrm{C}$ & $\mathrm{C}$ & $\mathrm{C}$ & $\mathrm{C}$ & $\mathrm{C}$ \\
\hline
\end{tabular}


This part of the survey uses a table of questions, view as separate questions instead?

7. To what extent your organisations co-operated on any innovation activities with any of the following

\begin{tabular}{|c|c|c|c|c|c|}
\hline & $\begin{array}{l}\text { Strongly } \\
\text { Disagree }\end{array}$ & Disagree & $\begin{array}{c}\text { No } \\
\text { Opinion }\end{array}$ & Agree & $\begin{array}{c}\text { Strongly } \\
\text { Agree }\end{array}$ \\
\hline Other healthcare organisations & $\mathrm{C}$ & $\mathrm{C}$ & $\mathrm{C}$ & $\mathrm{C}$ & $\mathrm{C}$ \\
\hline $\begin{array}{l}\text { Suppliers of equipment, materials, services or } \\
\text { software }\end{array}$ & $\mathrm{C}$ & $\mathrm{C}$ & $\mathrm{C}$ & $\mathrm{C}$ & $C$ \\
\hline Patients or end users & $\mathrm{C}$ & $\mathrm{C}$ & $\mathrm{C}$ & $\mathrm{C}$ & $\mathrm{C}$ \\
\hline
\end{tabular}

This part of the survey uses a table of questions, view as separate questions instead?

8. To what extent the following factors were important in constraining innovation activities \begin{tabular}{|l|l|l|} 
Not Important at AllSomewhat Important Neutral Important Very Important \\
\hline
\end{tabular}

Excessive perceived economic risks $C$

Availability of finance
G

0

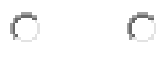

$B \quad$

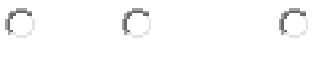

Page 4: Section 3 - General Information regarding yourself

Finally, please answer the following questions related to yourself. This will allow the assessment of your organisation's environment. We would like to remind you that the survey is anonymous and the following data will only be used for conducting the investigation.

9. Please indicate your current residence

Greece

The UK 
10. What is your job title?

11. What is your work experience with the organisation?
- 0-5 years
6-10 years
11-15 years
16-20 years
C. More than 20 years

12. What is your highest level of educational qualification?
High school
College diploma
Professional qualification
Undergraduate degree
Postgraduate Master's degree
C PhD

13. In the box below, please write any additional comments that you would like to make

Please submit your contact information below to enter to win the prize

14. E-mail address

More info

\section{Page 5: Final Page}

Thank you for completing this survey. 